\title{
Circunstancia familiar y entrada en la vida política del joven poeta valenciano Joan Escrivà (1461-1462)
}

The young valencian poet Joan Escrivà: Family circunstances and his entrance in political life (1461-1462)

Agustín Rubio Vela rubiovela@yahoo.es

Independent Scholar

Resumen: El presente estudio aporta referencias documentales sobre la vida del poeta valenciano Joan Escrivà y, especialemte, sobre su trayectoria vital en los años 1461 y 1462, período en que entró en la vida política.

Palabras clave: Joan Escrivà, poesia, Valencia, siglo XV, política

Abstract: The present study provides documentary references to the life of the valencian poet Joan Escrivà and specially on his own life in the year 1461 and 1462, period in which he entered in his political life

Keywords: Joan Escrivà, poetry, Valencia, 15th century, politics 
Las documentadas páginas que dedicó Martí de Riquer en su Història de la literatura catalana a la vida y obra del poeta cuatrocentista Joan Escrivà, «un dels millors de la seva època» (1964: 261-262 y 354-364), ampliadas y matizadas tres décadas después por él mismo (1993), proporcionaron abundantes datos acerca de un autor hasta entonces conocido casi exclusivamente por haber sido contertulio de Joan Roís de Corella en la casa de Berenguer Mercader. Estudios más recientes han venido a añadirse a los del maestro. Entre ellos destacan, por su amplitud y rigor, los de Ivan Parisi, quien lo considera «el membre socialment, políticament i literàriament més conegut de la família Escrivà», un linaje de la pequeña nobleza de Valencia que sitúa «de ple dret entre les grans nissagues nobiliàries del Renaixement europeu» (2008-2009: 57 y 66).

Tanto las primeras investigaciones como las últimas se refieren a la fase de madurez y plenitud del autor, que inició una brillante carrera política de la mano de Fernando el Católico. En 1477, siendo todavía príncipe, lo nombró mestre racional del reino de Valencia, un cargo que ostentaría desde 1479, fecha en que se hizo efectivo el nombramiento, hasta 1501 (Cruselles 1989: 107 y 112-121). Le encomendó asimismo la receptoría de bienes del Santo Oficio, que desempeñó entre los años 1482 y 1487 (Tomás Botella, 2013). Y finalmente lo envió como embajador a Nápoles, donde vivió desde 1494 hasta 1499 (Parisi 2008-2009: 66-71). Frente a la abundancia de información de estas décadas, las noticias documentales referidas a tiempos anteriores siguen siendo hoy casi tan escasas como hace dos décadas, cuando Riquer escribió: «Las primeras noticias que he recogido sobre él son del año 1472 cuando, como capitán de una compañía de jinetes en la que formaban caballeros de las más ilustres familias valencianas, Joan Ram Escrivà, entonces jurado de la ciudad de Valencia, acudió en socorro de Juan II en los momentos finales y decisivos de la guerra civil catalana» (1993: 89). Palabras que Parisi, pasados dos lustros, suscribió: «Las primeras noticias que tenemos de él se remontan a 1472, cuando aparece como capitán de una compañía de jinetes y jurado de la ciudad de Valencia» (2004: 57).

A esos años de juventud, la etapa más desconocida de su biografía, nos referiremos en este trabajo, cuyo eje y punto de partida será un suceso de 1461 que supuso un importante giro en su vida y que hubo de tener, por lo insólito, bastante resonancia en la ciudad.

\section{El descubrimiento de un engaño y el cambio de nombre}

El padre de nuestro personaje pertenecía a una familia del estamento militar. Era el doncel Ximén Pérez Escrivà de Romaní (también figura como Ximén Pérez de Romaní y como Ximén Pérez Escrivà), que en 1443 ejercería un cargo relevante, el de justícia civil de Valencia. ${ }^{1}$ En 1428 contrajo matrimonio con Beatriu Ram, hija del doctor en leyes y protonotario real Pere Ram, miembro de una acaudalada e influyente familia de Morella. ${ }^{2}$ De

\footnotetext{
1 La elección tuvo lugar el 22 de diciembre de 1442. Gracias a este episodio sabemos que tenía el domicilio en la parroquia de Sant Esteve: «E encontinent e aquí mateix lo dit honorable batle donà e publicà per justícia civil al dit hun any propvinent l'honorable N'Eximén Pérez Scrivà, generós, habitant de la dita ciutat, dat e nomenat a aquest offici per la parròquia de Sent Stheve». Prestó juramento el 25 de diciembre, primer día del siguiente año de 1443 según el calendario de la natividad (Archivo Municipal de Valencia [AMV], Manuals de Consells [MC] 32, ff. 105r y 108r-v).

2 En 1428, el clavari dels censals de Valencia pagaba «a l'honorable N'Eximén Peres de Romaní, holim Escrivà, donsel», el valor de unos censos que tres años antes, en 1425, «foren venuts e caregats a l'honorable En Tomàs Ram, abitador de la villa de Morella», y que éste en 1426, en carta pública realizada en Morella, «feu regonexença a l'honorable micer Pere Ram, frare seu, aver conprat lo dit sensal a hobs e de peqúnia pròpia del dit micer Pere». Dos años más tarde, Pere Ram los transfirió, «en paga prorata de aquells XXXXIIm sous per ell qunstituhits en dot, al damunt dit N’Eximén Peres», al contraer nupcias «ab la honorable Na Beatriu, donsella, filla sua» (AMV, Quitaments de Censals [QC] W-2, f. 52r). Otros documentos censales confirman la fecha de 1428 como la del matrimonio, que Parisi sitúa hacia 1435 (2008-2009: 59). Así dice uno de ellos: Lluís de Calatayú, caballero, en 1443, año siguiente al de la muerte de su padre, realizó una transacción con rentas censales compradas originariamente a la ciudad de Valencia el 27 de marzo de 1425 por Tomàs Ram, habitante de la villa de Morella. En 1426 las transfirió a su hermano, el protonotario Pere Ram («Thomas Ram, emptor [...], fecit cessionem et transportationem venerabili Petro Ram, legum doctori, fratri suo, prothonotario domini regis et suis»). En 1428,
} 
la unión nacieron dos hijos varones. El mayor, homónimo del padre, era el llamado a heredar los bienes de la familia. Joan Escrivà fue el menor, por lo que es posible que, como en tantos otros casos de segundones, estuviera destinado a ocupar un beneficio eclesiástico. No fue así, ya que heredaría los bienes de su tío materno, Ferrer Ram, un alto funcionario de Alfonso el Magnánimo - también protonotario- que hizo carrera en Nápoles, donde falleció hacia 1449 tras haber amasado una gran fortuna (Riquer 1993: 89; Parisi 2008-2009: 67).

Un panorama familiar apacible en apariencia. Sin embargo, en el seno de aquel hogar se escondió durante más de una década un engaño que quedaría desvelado en 1461. Lo sabemos por una carta redactada no mucho después, en febrero de 1462, por los jurats de Valencia, que informaron al rey Juan II del hecho (doc. núm. 2 del apéndice). Se trataba de un asunto privado, referido a una herencia, pero que podía afectar negativamente a las finanzas municipales, razón por la cual decidieron dar cuenta al monarca y pedir su intervención para evitar males mayores. En la misiva relataban que, hacía doce años, tras el fallecimiento en tierras itálicas del alto dignatario Ferrer Ram, su hermana Beatriu, argumentando que había muerto abintestato, había solicitado del justícia civil de Valencia ser reconocida sucesora y heredera «en tots los béns que foren del dit son germà, axí vinculats com altres». Así fue declarada por sentencia, y desde entonces había procedido como propietaria legítima de aquellos bienes. Hasta que unas cuantas semanas antes, Joan, el hijo menor de Beatriu, descubrió el testamento de Ferrer Ram, que no murió, por tanto, abintestato, y que había declarado heredero universal a él, el sobrino menor. Pese a no ser demasiado explícita en detalles, la epístola de los jurats, que permite imaginar el estado de ánimo de aquel hijo engañado, alude a las circunstancias del hallazgo: en la casa paterna, dentro de una caja, se ocultaba el instrumento, «fet en Nàpols sots cert kalendari, sots signat de mans de nou testimonis ultra la clausura del notari que reebé e signà aquell». Fue así como, de manera inesperada, la gran fortuna del tío pasó a manos del sobrino: «per lo qual se descobre que lo dit micer Ferrer, entre les altres coses, ha instituiit hereu seu universal lo dit Johanot Ram, nebot seu». Los ediles se hacen eco del inmediato cambio de nombre de Joan Escrivà, el hijo más joven de Ximén Pérez Escrivà de Romaní y Beatriu Ram, ahora llamado Joan Ram: «un son fill apellat Johanot Scrivà e ara se appella Johanot Ram».

La carta confirma algo que ya era sabido gracias a estudios de Parisi: Joan Escrivà, heredó a su tío, quien impuso en el testamento el cambio de apellido. ${ }^{3}$ Pero, sobre todo, explica el porqué del largo tiempo transcurrido entre el fallecimiento del protonotario y la apertura del testamento, así como el cambio de titularidad de unos bienes que habían sido temporalmente de Beatriu Ram. Como Joan pudo demostrar que él era el legítimo heredero, pidió y obtuvo la propiedad, que pasó de las manos de su madre a las suyas. Ahora bien, como Beatriu había vendido algunas de las rentas que poseía su hermano en el censal de la ciudad de Valencia, surgió un complicado problema, pues Joanot las reclamó ante los tribunales de justicia, exigiendo que fueran confiscadas a los actuales propietarios, compradores de buena fe a juicio de los ediles,

Pere Ram las vendió a Ximén Pérez de Romaní, olim Escrivà, en pago de la dote de su hija Beatriu («in et pro dote venerabilis dompne Beatricis, filie sue uxorque honorabilis Eximini Petri de Romanino, olim vocati Scrivà, domicelli, habitatoris Valentie»). En 1440, ambos cónyuges («Eximinus Petri de Romanino alias Scrivà et venerabile domina Beatrix, eius uxor») las vendieron a Ximén Pérez de Calatayú, padre de Lluís, por quien fueron heredadas al morir el primero (id., Protocols, Jaume Beneyto, r-7, s. fol.; 13 de julio de 1443).

3 «Nel documento n. 43 del lío I2 dell'archivio Sástago, infatti, Jaume Gisquerol, notaio della corte del governatore della città di Valencia, afferma che il giorno 4 dicembre 1461 venne da lui il donzell Johanot Escrivà, figlio del defunto Eiximèn Pérez (I) Escrivà de Romaní, riferendogli di essere venuto in possesso di una pergamena che si trovava in una cassa, custodita nella casa dove aveva vissuto il padre, contenente l'ultimo testamento di Ferrer Ram, protonotario di Alfonso il Magnanimo e suo zio materno in quanto fratello di sua madre Beatriu, composto a Napoli il 21 settembre 1448 per mano del notaio Gabriele de Risio. Nel testamento Ferrer Ram nominò suo erede universale, per i beni ed i diritti da lui acquisiti sia nella città di Napoli che in quella di Valencia, suo nipote Joan Escrivà con l'unico vincolo che questi mantenesse il cognome Ram» (2006-2007: 104). El documento que publicamos en el apéndice (núm. 7), confirma, con alguna pequeña variante, estos datos sobre el último testamento del protonotario, hecho en la ciudad de Nápoles el 25 de septiembre de 1448 ante «En Gabriel de Risio», y publicado en Valencia el 4 de diciembre de 1461 por el notario de Valencia Jaume Gisquerol, en cuyo poder obraba. 
pues las adquirieron con la convicción de «Na Beatriu ésser verdadera hereva e successora en tots los béns del dit micer Ferrer Ram». La complicación era mayor aún al haber sido ella denunciada a su vez por los compradores. Ante la enojosa perspectiva de una multitud de pleitos que podía erosionar la confianza en el sistema crediticio, esencial para el funcionamiento de la ciudad y de su gobierno, los ediles pidieron al monarca que dictara orden de sobreseimiento a los jueces responsables de dictar sentencia sobre las reclamaciones, dando por consumados los hechos.

Joan Escrivà cambió el apellido paterno por el materno por algo que Martí de Riquer consideraba obvio y que la documentación confirma plenamente: «sin duda por motivo de alguna sucesión materna, adoptó el [nombre] de Joan Ram Escrivà, a veces seguido de Romaní, y no raramente, en documentos oficiales y notariales, aparece denominado «Joan Ram olim [: antes] Escrivà» (Riquer 1993: 89). El maestro sabía muy bien lo que decía. ${ }^{4}$ En los testamentos de la época eran habituales las cláusulas que obligaban al heredero a llevar el apellido del testador. En la propia familia Escrivà, los primogénitos —el abuelo, el padre y el hermano de Joan - estaban obligados a ser portadores del apellido Romaní en virtud de un vínculo testamentario establecido a finales del siglo XIV por Elisenda de Romaní para la baronía de Beniparrell «per ço que lo seu e nostre nom e cognom no romangués en oblit» (Baydal Sala 2008: 129). Ferrer Ram obligó a Joan Escrivà a cambiar de apellido para entrar en posesión de los bienes; de ahí aquellas palabras de los jurats en la carta al rey: «un son fill apellat Johanot Scrivà e ara se appella Johanot Ram». ${ }^{5} \mathrm{Y}$ así se hizo llamar en adelante, efectivamente. El 2 de agosto de 1462 actuaba ante notario: «Ego, Iohannes Ram, olim Scrivà, domicellus, habitator Valentie, heres universalis honorabilis Ferrarii Ram, utriusque iuris doctoris quondam, consiliarii et prothonotarii serenissimni domini regis Alfonsi, inmortalis memorie». ${ }^{6}$

\section{La herencia de Ferrer Ram, curial del Magnánimo}

Las misivas de los jurats no dejan lugar a dudas de la influencia que llegó a tener en la corte partenopea del Magnánimo el valenciano «micer Ferrer Ram, doctor en leys, conseller e prothonotari del senyor rey». ${ }^{7}$ En 1443 le comunicaban la inmediata llegada allá del racional Manuel Suau con el encargo de resolver asuntos de interés para la ciudad, y, apelando al sentimiento patrio, le pedían apoyo, «e pendre tots los affers de la dita ciutat, com a fill de aquella, per propris e en special recomendació». El año siguiente agradecían al dignatario «la bona recepció e acolliment» que había dispensado a Suau, quien a la vuelta informó de tan calurosa acogida: «És veritat que a nosaltres no és cosa nova, car grans dies són passats haveu demostrat per obra en moltes maneres amar aquesta ciutat e lo bé públich d'aquella». ${ }^{8}$

4Se ha escrito recientemente que «esta hipótesis de Riquer [...] no es, hoy por hoy, un hecho probado más allá de la simple sospecha» (Pérez Bosch 2011: 148). Sin embargo, Parisi, como acabamos de ver, varios años antes había demostrado documentalmente que Ferrer Ram institutó heredero universal de sus bienes a su sobrino «con l'unico vincolo che questi mantenesse il cognome Ram» (2006-2007: 104).

5 Completamente erradas son estas palabras de Jordi Ventura sobre los apellidos que llevó nuestro personaje a lo largo de su vida: «durant almenys tres anys, de 1485 a 1487, Joan Ram encara signà el seu nom així, sense afegits; però, tal vegada perquè abundaven les condemnacions [inquisitorials] de persones que portaven el seu mateix cognom, l’anà canviant pel del seu ofici, Escrivà, i, més tard, a base del senyoriu de Romaní que posseïa, esdevingué Escrivà de Romaní» (1978: 156).

6 AMV, Protocols, Jaume Beneyto r-18, s. fol. (1462,agosto, 2).

7 «Ferrarius Ram, legum doctor, consiliarius et prothonotarius domini regis, civis Valentie» (AMV, Protocols, Jaume Beneyto r-8, s. fol.; 1444, noviembre, 3). Tenía casa en Valencia: «...en la parròquia de Sent Salvador, davant l'alberch qui fon de l'honorable micer Ferrer Ram...» (id., Claveria Comuna. Manuals de Albarans [CC] J-66, f. 4r-v; 1452, junio, 22).

8 AMV, $L M$ 20, ff. 179v (1443, noviembre, 2) y 222v-223r (1444, agosto, 28). Entre los gastos realizados en Nápoles por el racional Suau hay pagos

SCRIPTA, Revista internacional de literatura i cultura medieval i moderna, núm. 3 / juny 2014 / pp. $46-70$

ISSN: 2340-4841 · doi:10.7203/SCRIPTA.3.3788 
Agustín Rubio Vela. Circunstancia familiar y entrada en la vida política del joven poeta valenciano Joan Escrivà (1461-1462)

En 1445 volvió temporalmente al reino de Valencia. Era entonces, además de consejero y protonotario, batle de Morella — de la villa y sus aldeas_- y como tal juraba solemnemente, en presencia del batle general Berenguer Mercader y en casa de éste, a instancias del racional Suau y del sindic de la ciudad, Joan Marromà, cumplir lo acordado en 1430 entre la capital y el rey, que obligaba a éste a pagar con las rentas de Morella una elevada deuda contraída por el soberano con aquélla. Entre los testigos del acto se encontraba el doncel Ximén Pérez Escrivà, ${ }^{9}$ marido de Beatriu Ram y cuñado de Ferrer Ram (docs. núm. 1 y 2 del apéndice).

El protonotario, casado con Iolant de Valldaura, hija del caballero Guillem Crespí de Valldaura, ${ }^{10}$ permaneció algún tiempo en Valencia antes de retornar a Nápoles, donde debió morir tres años después. Era hombre pudiente. Hay noticia de que durante su última estancia en la capital del reino invirtió importantes cantidades de dinero en la compra de censos de la deuda municipal, que pasaron a manos de su hermana Beatriu cuando falleció. El 18 de enero del año 1449, el justicia civil sentenció que, por haber muerto abintestato, sus bienes -y, por tanto, las rentas censales de las que era titular- pertenecían a aquélla. ${ }^{11}$ Pero el jurista poseyó también censos que no fueron comprados por él, sino por su madre, Beatriu, esposa del protonotario real Pere Ram, en 1431, que se las donó cuando contrajo matrimonio. A la muerte de éste también pasaron a ser propiedad de su hermana, «iure vinculi et successionis ab intestato», en virtud de la ya aludida sentencia judicial de 19 enero de $1449 .{ }^{12}$

A partir de esta fecha, el momento en que el justícia civil declaró «hereva de l'honorable micer Ferrer Ram abintestat» a la madre del entonces niño Joan Escrivà, ella actuó, juntamente con su marido, como propietaria legal de las rentas censales que habían sido del protonotario. Unos meses más tarde, el 18 de agosto de ese mismo año, Beatriu y Ximén concertaban el matrimonio de su hija con el noble Lluís Pardo de la Casta y, como parte de la dote de cincuenta mil sueldos de «Na Margalida, filla de aquells, e ab pacte fet entre aquells contengut en un capítol de les cartes nubcials entre aquells», le transfirieron algunas de dichas rentas. Entre los días 17 y 20 de febrero del año siguiente murió el joven esposo, por lo que la propiedad fue restituida a la viuda - esperaba un hijo cuando se produjo el óbito— por decisión de «los nobles mossén Johan Pardo de la Casta, e mossén Carroç de Vilaragut, e lo dit N’Eximén Pérez Scrivà, axí com a tudors e curadors del postumus del dit noble mossén Luís Pardo». Más tarde, el 24 de abril de 1451, las rentas volvían a servir de

\footnotetext{
«a l'honorable mossén Johan Olzina, secretari, e a micer Ferrer Ram, prothonotari del senyor rey, axí per treballs, salaris e per dret de segell de les provisions del senyor rey en favor de la dita ciutat impetrades» (id., CC J-61, f. 26v-27r; 1444, diciembre, 22).

9 «Noverint universi quod anno a nativitate Domini $\mathrm{M}^{\circ} \mathrm{CCCC}^{\circ} \mathrm{XXXXV}^{\circ}$, die videlicet lune, computata quinta mensis aprilis, honorabilis et providus vir Ferrarius Ram, legum doctor, consiliarius et prothonotarius domini regis, civis Valentie, baiulus ville et aldearum de Morella, constitutus personaliter in presentia honorabilis et providi viri Berengarii Mercader, militis, consiliarii eiusdem domini regis et baiuli generalis regni Valentie, intus suam habitationem quam fovet in dicta civitate [...] Presentibus pro testibus ad hec vocatis pariter et assumptis, honorabilis Petro Mercader, milite, Eximini Petri Scriva, domicello, habitatoribus, Francisco Palomar, scriptore et Iacobo Martí, virgario dicti honorabilis baiuli generalis» (AMV, Protocols, Jaume Beneyto r-8, s. fol.; 1445, abril, 5).
}

10 En 1478, «Ludovicus Crespí, miles», realizó una transacción con censos «originaliter onerati magniffice Yolanti Valldaura, uxori magniffici Ferrarii Ram, legum doctor, civis dicte civitatis», en 1448. Una sentencia judicial declaró en 1451 que pertenecían a Guillem Crespí, padre de Iolant («declaratum fore prefatum censuali, inter alia bona, pertinere magniffico Guillermo Crespí, militi, eiusdem Yolantis genitori») y de Lluís Crespí, declarado heredero al morir aquél en 1449 (AMV, Protocols, Jaume Ximeno t-10, s. fol.; 1478, marzo, 6).

11 En el quitament de un censo leemos: «Dictus autem honorabilis Ferrarius Ram obivit ab intestato et sucessit in bonis eius venerabilis dompna Beatrix, soror sua uxorque honorabilis Eximini Petri de Romaní, alias Scrivà, domicelli, habitatoris Valentie, ut constat quadam sententia seu declaratione lata per honorabilis tunc iustitiam in civilibus eiusdem civitatis decima octava die ianuarii anno a nativitate domini $\mathrm{M}^{\circ} \mathrm{CCCC} \mathrm{XXXXVIIII}^{\circ}$, clausa et subsignata manu discreti Petri Navarro, notarii, alterius ex scribis curie civilis» (AMV, Protocols, Jaume Beneyto, r-16, s. fol.; 1458, mayo, 23).

12 AMV, Protocols, Jaume Ximeno t-3, s. fol. (1471, agosto, 22).

SCRIPTA, Revista internacional de literatura i cultura medieval i moderna, núm. 3 / juny 2014 / pp. 46-70

ISSN: 2340-4841 · doi:10.7203/SCRIPTA.3.3788 
dote a Margarida, «col locant-se en matrimoni segonament ab lo noble En Pere Boÿl, menor de dies». ${ }^{13}$ Hay noticia de otros dos censos que acabaron siendo de ella tras ser heredados por Beatriu Ram: uno había sido comprado en 1431 por «Na Beatriu, muller de l'honorable micer Pere Ram, prothonotari del senyor rey»; ${ }^{14}$ el otro fue adquirido en 1425 por un hermano de éste, «En Thomàs Ram, habitador de la vila de Morella». ${ }^{15}$

Parece evidente, pues, que los padres de Joan Escrivà, al ocultar el testamento, no buscaron exclusivamente un beneficio material, sino también un mayor rango social. Lo ponen de relieve los dos matrimonios sucesivos de Margarida, cuya elevada dote permitió a los Escrivà establecer vínculos de sangre con dos linajes de tanta alcurnia en Valencia como eran los Pardo de la Casta y los Boill. Naturalmente, ello perjudicaba al heredero legítimo, su hijo menor, víctima evidente, no ya de la injusticia, sino del desamor paterno. Posiblemente buscaran también el beneficio y encumbramiento del primogénito, Ximén Pérez de Romaní Escrivà, que en 1456 contrajo matrimonio con Isabel Serra, de la que enviudó en 1461 (Parisi 2008-2009: 64). El 16 de noviembre de ese mismo año, un censo de la herencia de Ferrer Ram fue vendido a «Manuel Vives, mercator, civis Valentie», por Beatriu Ram, Ximén Pérez de Romaní, su marido, y Ximén Pérez de Romaní Escrivà, hijo de ambos. ${ }^{16} \mathrm{El}$ hecho de figurar éste en la transacción permite sospechar que, como primogénito, estaba destinado a ser el propietario de los bienes del protonotario.

\section{Joanot Ram, olim Escrivà, heredero de Ferrer Ram}

Cuando Joanot Escrivà, reconocido como heredero universal de Ferrer, ya se llamaba Ram, los censos municipales de los que el tío fue titular pasaron de las manos de su madre a las suyas. En 1462, necesitado

13 AMV, QC W-7, ff. 36r-37v.

14El 13 de junio de 1438 pasó a ser de misser Ferrer Ram con ocasión de su matrimonio con la hija de mossén Crespí de Valldaura. Más tarde, «lo dit micer Ferrer Ram és mort sens testament e succehí en los béns e drets de aquell la honorable Na Beatriu, jermana sua, muller de l’honorable En Eximén Pérez Scrivà de Romaní, donzell, per dret de vincle e succesió abintestat, e mostra’s ab sentència donada per lo magnífich justícia civil a XVIIII de jener de l'any MCCCCXXXXVIIII', rebuda per lo discret En Pere Navarro, notari, scrivà de la dita cort. E aprés los dits N'Exemén Pérez Scrivà e Na Beatriu, sa muller, hereva, succehint qui dessús a l’honorable micer Ferrer Ram, en pagua solució de aquells Lm sous constituhits en dot al noble mossén Luís Pardo, cavaller, ab la honorable Na Margarita, donzella, filla de aquells, donaren al dit noble entre les altres coses los dits DCCXXXIII sous IIII, axí com a béns dotals inextimats, quant a l'usufruyt durant lo matrimoni, e quant a la proprietat a la dita Na Margarita, donzella e muller sdevenidora de aquell. Ab carta rebuda per lo dit honorable En Pau Rosell, notari, a XXI de febrer de l'any MCCCCL, los nobles mossén Johan Pardo de la Casta, mossén Carroç de Vilaragut e lo dit honorable N’Eximén Pérez de Romaní Scrivà, curadors del pòstum del dit noble mossén Luís Pardo quondam, segons consta de la tutela e cura per lo testament de aquell fet en València a XVII de febrer del propdit any, e publicat a XXI dels dits mes e any, en poder del dit notari, feren restitució a la dita Na Margarita, vídua, dels dits DCCXXXIII sous IIII diners. La qual dita noble Na Margarita, col locant-se en matrimoni segonament ab lo noble En Pere Boÿl, menor de dies, constituhí, entre les altres coses, en e per dot de aquella los dits DCCXXXIII sous IIII diners, e axí 's mostra ab carta rebuda per lo discret En Johan Çaposa, notari, a XXIIII d'abril de l'any MCCCCLI, la qual carta clogué lo discret En Nicolau Çaposa, notari regent los libres de aquell». El 13 de noviembre de 1454 , Pere y Margarida vendieron el censo «a la dita noble $\mathrm{Na}$ Caterina Boÿl e al dit En Luís Boÿl», y acabó siendo exclusivamente de este último «per la donació feta a quell per la dita noble $\mathrm{Na}$ Caterina Boÿl, mare sua, de tots los béns de aquella» (AMV, QC W-7, ff. 37v-38v).

$15 \mathrm{Al}$ año siguiente reconoció su propiedad a «micer Pere Ram, jermà seu, doctor en leys», quien en 1428, «col locant en matrimoni la honorable Na Beatriu, donzella, filla sua, ab lo honorable N’Eximén Pérez de Romaní Scrivà, donzell, habitador de la dita ciutat de València», los transfirió a éste como parte de la dote. En 1430, Beatriu y Ximén vendieron una porción de esa renta censal «a l'honorable En Guillem Scrivà, donzell», que con el tiempo pasó de nuevo a ser propiedad suya y establecida como dote de Margarida (AMV, QC W-7, f. 39r-v).

16Vives cancelaba el censo el 23 de mayo de 1458, que había sido comprado originariamente el 16 de mayo de 1448 por «honorabili Ferrario Ram, legum doctori, consiliario et prothonotario domini regis», y que al morir abintestato pasó a Beatriu, su hermana: «Dictus auten honorabilis Ferrarius Ram obivit ab intestato et sucessit in bonis eius venerabilis dompna Beatrix, soror sua, uxorque honorabilis Eximini Petri de Romaní, alias Scrivà, domicelli, habitatoris Valentie, ut constat quadam sententia seu declaratione lata per honorabilis tunc iustitiam in civilibus eiusdem civitatis decima octava die ianuarii anno a

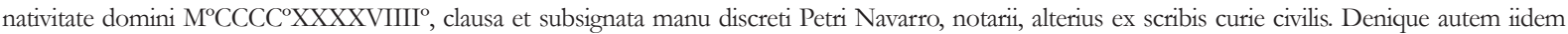
honorabilis Eximinus Petri de Romaní et dompna Beatrix eius uxor ac Eximinus Petri de Romaní Scrivà, domicellus, eorum filius, vendiderunt et alienarunt dictos quingentos solidos censuales michi et meis cum omnibus iuribus suis» (AMV, Protocols, Jaume Beneyto, r-16, s. fol.; 1458, mayo, 23). 
de dinero — quizá para adquirir lo que necesitaba en su nueva vida de rico propietario-, percibía diez mil sueldos del clavari dels censals de la ciudad por extinción de uno de tales censos. Era una operación habitual: los titulares recuperaban el capital invertido en la compra inicial (carregament) y el contrato que les había permitido percibir la renta quedaba cancelado (quitament) ${ }^{17}$ El documento es muy ilustrativo. Joan hace constar, discretamente, que con anterioridad había actuado como titular su madre, «venerabilis dompna Beatrix, mater mea [...], tanquam succedens ab intestato in omnibus bonis et iuribus dicti Ferrarii Ram». Y repite: «dicta venerabilis dompna Beatrix, mater mea, per mortem dicti honorabilis Ferrarii Ram, fratris sui, obtinuisset successionem ab intestato omnium bonorum et iurium dicti fratris sui...» También se alude a algunos de los problemas legales de la usurpación, como la querella con los hermanos Lluís y Llorenç Johan por la compra a su madre de un censo, que Joan consideraba ilegal de raíz, pues el propio lugarteniente de gobernación, Lluís de Cabanyelles, lo había reconocido como el heredero de Ferrer Ram: «vocatis et auditis ad plenum dicta honorabilis mater mea et ipsis Ludovico et Laurentio Iohannis, per honorabilem Ludovicum de Cabanyelles, [...] declaratum et sententialiter fuit expresse me fore heredem dicti honorabilis Ferrarii Ram».18

En marzo y abril de 1463, por medio de su procurador, Jaume Gisquerol —el notario al que acudió con el testamento y que lo publicó-, recibía importantes cantidad por quitament de otras rentas censales de la herencia, ${ }^{19}$ y en diciembre era receptor de 30.000 sueldos por el mismo concepto, para lo cual la ciudad tuvo que buscar cuatro compradores, quienes, mediante una aportación de 7.500 sueldos cada uno, hicieron posible la entrega a Ram de tan cuantiosa suma. ${ }^{20}$ En 1464, se registra otro pago por otro quitament «a l'honorable En Johanot Ram, donzell, habitador de la dita ciutat, hereu universal de tots els béns e drets que quondam foren del magnífich micer Ferrer Ram, doctor en leys, prothonotari del senyor rey», y vuelve a indicarse que el testamento, hecho en Nápoles en 1448, fue «publicat en la ciutat de València a IIII de dehembre de l'any MCCCCLXI, en poder del discret En Jacme Gisquerol, notari» (doc. núm. 7 del apéndice). Los trece años que mediaban entre ambas fechas, la de redacción y la de apertura, marcaban el comienzo y final del engaño y expolio del joven Joan Escrivà por su propia familia.

Al llevar su caso ante los tribunales exigió la anulación las transacciones censales hechas por la madre. Pero ello suponía algo más que un perjuicio para quienes compraron de buena fe: era un descrédito para el sistema

17 Sobre el mecanismo de los censales y la documentación que reflejan las operaciones realizadas con ellos, el excelente estudio de García Marsilla contiene páginas aclaratorias (2002, 186-189).

18 AMV, Protocols, Jaume Beneyto, r-18, s. fol. (1462, agosto, 2). Pocos meses después, el gobierno municipal autorizaba la venta de ese mismo a misser Miquel Albert: «Item, prestaren lur assentiment que, per quitar d'En Johan Ram, donzell, siscents sexanta sis sous, huyt diners censals, dels quals ha fermat quitament, sien carregats a micer Miquel Albert, a lurs despeses, iuxta lo dit consell» (id., MC 37, f. 30r; 1462, noviembre, 6). En el documento que registró esta venta, el subsíndico de la ciudad indica que las rentas censales objeto de la transacción, compradas el 15 de febrero de 1431 por Beatriu, mujer de Pere Ram, tras haber tenido varios propietarios («diversis titulis intermediis»), llegaron a manos de Joan Ram, que solicitó su cancelación "pro aliquibus suis necessitatibus et negotiis expediendis» (id., ibid.; 1462, noviembre, 15).

19 El procurador («ego, Iacobus Gisquerol, notarius, civis Valentie, procurator ad scripta specialiter constitutus per honorabilem Iohannem Ram alias Scrivà, domicellum, habitatorem Valentie, heredem universalem honorabilis Ferrarii Ram») dejaba constancia de que la madre de su representante había procedido como heredera con anterioridad («venerabilis dompna Beatrix, mater dicti principalis mei, uxorque honorabilis Eximini Petri Scrivà, domicelli, patris mei dicti principalis dicti, per mortem honorabilis Ferrarii Ram, fratris sui, obtinuisset successionem ab intestato bonorum omnium et iurium dicti fratris sui»), y aludía al pleito con los Johan. así como a la declaración de Joan como heredero (AMV, Protocols, Jaume Beneyto, r-18, s. fol.; 1463, marzo, 29; y abril, 4).

20 AMV, Protocols, Jaume Beneyto, r-19 (1463, diciembre, 19): «hoc modo, videlicet, per manus venerabilis domine Damiate, domicelle, filie honorabilis Laurentii Ballester, quondam civis Valentie et sponse honorabilis Aduardi Guillermi Scrivà, domicelli, septem mille quingentos solidos, et per manus venerabilis Ludovici de Bellviure, mercatoris dicte civitatis, alios septem mille quingentos solidos, et per manus venerablis Iacobi Martínez de Sentàngel, alios VIIm quingentos solidos, et per manus venerabilis Egidii Roiz, filii Anthonii Roïz, domicelli, restantes alios septem mille Dtos solidos». Vid. también: id., ibid., s. fol. (10 marzo 1464). 
Agustín Rubio Vela. Circunstancia familiar y entrada en la vida política del joven poeta valenciano Joan Escrivà (1461-1462)

de deuda. De ahí que los jurats, interesados en alejar cualquier peligro que pusiera en riesgo las finanzas de la ciudad, pidiesen al rey que ordenara suspender la ejecución de las sentencias judiciales, contrariamente a lo que Joan Ram exigía. Algunos indicios apuntan que ocurrió así. Años después, en el quitament de un censo de Lluís Boil procedente de la herencia de Ferrer Ram, anotó el clavari: «E jatsia en lo dit censal hagués algunes empares, e senyaladament per lo honorable En Johan Ram, donzell, aquelles, emperò, foren toltes e cancel lades, e per lo spectable governador manades cancel lar, ab ceda de la sua cort presentada per En Bernat Squer, porter, segons en aquells dits actes e cartes és pus larch contengut». ${ }^{21}$

\section{El matrimonio con Beatriu de Montpalau}

El hallazgo del testamento de Ferrer Ram tuvo lugar a comienzos de diciembre de 1461, un año crucial en la vida de Joan Escrivà en más de un sentido, puesto que también fue el del fallecimiento de su padre, Ximén Pérez Escrivà, y de su cuñada Isabel Serra, primera esposa de su hermano. ${ }^{22}$ Sabemos asimismo que éste último, homónimo del padre, un año después de haber enviudado, concertaba su segundo matrimonio —enero de 1462 - con Castellana, hija del acaudalado Joan de Montpalau. ${ }^{23}$ Estamos ante otro linaje que quedó unido por lazos de sangre al de los Escrivà. Doblemente, ya que diecisiete años después del enlace de Ximén con Castellana, Joan contrajo matrimonio con Beatriu de Montpalau, hermana de aquélla. ${ }^{24}$ Los dos hermanos casaron, pues, con dos hijas de Joan de Montpalau, que es conocido sobre todo por su enemistad juvenil con Joanot Martorell, del que era pariente, tras la negativa a unirse en matrimonio con Damiata, hermana del novelista.

En 1462, el mismo año en que casó con Castellana, Ximén iniciaba su carrera política en el ámbito municipal. Fue elegido entonces justícia criminal de Valencia. ${ }^{25} \mathrm{Y}$ en mayo del siguiente, en la renovación anual preceptiva del gobierno local, era nombrado jurat. ${ }^{26}$ En 1464 y 1467 figura entre los seis consellers representantes de los generosos en el consistorio. ${ }^{27}$ Casual o no, parece evidente que la llegada del doncel a los oficios de máximo rango del cursus honorum municipal coincide con su vinculación a los Montpalau. Más tardía es la presencia

21 AMV, QC W-7, ff. 36r-37v (1469-70).

$22 \mathrm{El}$ óbito de Ximén hubo de ser posterior al día 4 de agosto, fecha en que hizo testamento su nuera Isabel, en el cual figura un legado para los suegros, «que, per tant, aleshores encara vivien» (Parisi 2008-2009: 59 y 64). Efectivamente, desde enero del año 1462, la documentación censal presenta como viuda a Beatriu: «la honorable dona Na Beatriu Ram, muller de l'honorable N’Eximen Pérez de Romaní, alias Scrivà, donzell, quondan» (AMV, CCe I-78, f. 98r; 1462, enero, 19).

23 En el quitament de un censo municipal realizado durante la claveria de 1478-79, se indica que fue comprado originalmente en 1446 por «En Johan de Monpalau, donzell», y que éste, en las cartas nupciales, fechadas el 22 de enero de 1462, «col locant en matrimoni la dita Na Castellana, filla sua, ab lo dit magnífich N'Eximén Pérez, donà e transportà a aquella lo dit censal». El clavari registró así la entrega del dinero: «doní e paguí al magnífich N’Eximén Pérez de Romaní Scrivà, donzell, conseller del molt alt senyor rey e vizrey de la ylla de Cerdenya, e a la magnífica Na Castellana, muller sua» (AMV, QC W-7, f. 175r).

24 Castellana no falleció en 1462 como, por error o errata, se lee en Parisi (2008-2009: 62), que da noticia del tercer matrimonio de Ximén en 1480, en Cerdeña, con Rosa Gambella, de cuya muerte en 1482, «en circumstàncies misterioses», fue acusado. El 7 de febrero de 1480 , Castellana de Montpalau vivía aún y percibía rentas censales del clavari procedentes de la dote: «Item doní e paguí a l'espectable N’Eximén Pérez de Romaní, alias d'Escrivà, conseller e camarlench del senyor rey e virey del regne de Cerdenya, e Na Castellana, muller de aquell [...]. Enaprés lo dessús dit En Johan de Monpalau, col locant en matrimoni la dessús dita Castellana ab lo spectable N’Eximén Pérez de Romaní, alias Escrivà [...]» (AMV, CCo O-44, f. 107r-v).

25 AMV, MC 37, ff. $117 \mathrm{v}-118 \mathrm{r}$.

26 AMV, MC 37, ff. 69v-70r (segunda foliación). Su presencia en el gobierno municipal había sido irrelevante hasta esos años. Uno de los dos consellers elegidos por los generosos en 1451 fue «N’Eximén Pérez Scrivà» (AMV, MC 35, f. 109r; 1451, junio, 12), probablemente su padre.

27 AMV, MC 37, f. 131v (segunda foliación); id., MC 38, f. 124 (1467, mayo, 17).

SCRIPTA, Revista internacional de literatura i cultura medieval i moderna, núm. 3 / juny 2014 / pp. 46-70

ISSN: 2340-4841 · doi:10.7203/SCRIPTA.3.3788 
de su hermano en los órganos del gobierno urbano. El 1 de junio de 1471, de los seis jurats de la ciudad elegidos, los dos generosos fueron «En Berenguer Mercader e En Joan Ram, habitants», 28 que en 1472, como era habitual, siguieron presentes en el Consell en calidad de consellers representantes del estamento militar. ${ }^{29}$

Trece años después del óbito de Joan de Montpalau, ${ }^{30}$ Joan Ram Escrivà contrajo matrimonio con Beatriu de Montpalau, su hija, con la que tuvo cinco hijos (Parisi 2008-2009: 71). De ahí el nombre de Na Montpalaua d'Escrivà con el que fue conocida (Riquer 1964: 261; Riquer 1993: 88-89; Gascón, Sergi 1999: 190; Hauf i Valls 2013: 46). Los libros de claveria censal proporcionan, entre otros datos de interés, la fecha en que fueron firmadas las cartas nupciales: el 23 de julio de 1479. Como consecuencia de la firma de este documento, previa a la celebración del matrimonio, Joan pasó a ser propietario de un censo que poseía la familia Montpalau desde hacía más de medio siglo, como parte de la dote. ${ }^{31}$

Significativamente, ese mismo día, su hermano Ximén, que ostentaba los títulos de consejero y camarlengo real, así como el de virrey de Cerdeña, junto con su esposa Castellana, vendían otra renta censal que el padre de ésta les había transferido en 1462 como dote. La transacción fue realizada con la aprobación expresa y la rúbrica de Salelles, Francesc y Manuel, los hijos varones del difunto Joan de Montpalau, y de dos de las hijas, Sicília, soltera, y Iolant de Montpalau, casada con el caballero Lluís de Castellví, ${ }^{32}$ conocida por ello como Na Montpalaua de Castellví (Riquer 1963: 260-262; Riquer 1993: 88; Hauf 2013: 46). Así pues, el día de las nupcias de Joan, los siete hijos del prócer, tres hombres y cuatro mujeres, estaban presentes en Valencia y autorizaban con su firma transacciones censales relacionadas con la dote de dos de éstas. ${ }^{33}$

28 AMV, MC 38, f. 197r (segunda foliación). En el folio inicial de MC 39, leemos: «Primer libre de consells e stabliments de la ciutat de València començat aprés la festa de Cinquagesma de l'any de la nativitat de nostre Senyor mil CCCCLXXI, en la qual foren elets e reebuts en jurats de la dita ciutat los magníffichs En Berenguer Mercader, generós, En Loís Bou, ciutadà, En Joan Ram, generós, N’Anthoni del Miracle, En Joan Alegre e En Felip de Vesach, ciutadans».

29 AMV, MC 39, f. 110v

30 El 5 de abril de 1465 hizo su último testamento, publicado el 29 de octubre de 1466, en el que declaró heredero a su hijo, el caballero Salelles de Montpalau (AMV, Protocols, Jaume Ximeno, t-14, s. fol.; 1482, mayo, 13).

31 En el libro de quitaments del año 1481-82, el clavari dels censals registra la entrega «als magnífichs mossén Johan Ram Scrivà, cavaller, habitador de la dita ciutat, e a Na Beatriu, muller sua», del dinero correspondiente al valor de ese censo, comprado en 1416 por «mossén Berenguer Selelles, cavallen», heredado en 1446 por Joan de Montpalau, doncel, y a la muerte de éste por su hijo Salelles de Montpalau, quien lo transfirió «al dit magníffich mossén Johan Ram Scrivà, cavaller, en pagua rata de la dot de la damunt dita magnífica Na Beatriu, jermana del dit mossén Selelles, ab lo dit mossén Johan Ram, segons se mostra ab cartes nubcials rebudes per lo dit honorable N'Anthoni Barreda, notari, a XXIII de joliol de l'any MCCCCLXXVIIII, segons en les dites cartes és larch contengut» (AMV, QC W-8, ff. 53r-54r).

32 «Noverint universi quod nos, Eximinus Pérez de Romaní Scrivà, generosus, consiliarius et camarlengus serenissimi domini regis et pro eadem magestatem vicerex in regno Sardinie, et Castellana, eius uxor, scienter et gratis ambo simul et uterque nostrum insolum, cum expresso consensu, firma et voluntate et renunciationem vinculorum et aliorum iurium pertinentium magnificis Salello de Mompalau, Francischo de Mompalau, Manueli de Mompalau, Sicilie de Mompalau, domicelle, et Yolanti de Mompalau, uxori magnifici Ludovici de Castellví, militis, habitatoris civitatis Valentie, inferius firmantibus et laudantibus...» Se refieren a Joan de Montpalau como padre de todos ellos: «vigore testamenti seu codicillorum dicti magnifici Ioannis de Monpalau, genitori nostri» (AMV, Protocols, Jaume Ximeno, t-11, s. fol.). El 7 de febrero de 1480, el clavari dels censals pagó «a l'espectable N’Eximén Pérez de Romaní, alias d'Escrivà, conseller e camarlench del senyor rey e virey del regne de Cerdenya, e Na Castellana, muller de aquell», la cantidad correspondiente al quitament de los censos «originalment carregats a l'honorable En Johan de Monpalau, donzell», en 1446, por él transferidos el 22 de enero de 1462, «col locant en matrimoni la dessús dita Castellana ab lo spectable N’Eximén Pérez de Romaní, alias Escrivà» (AMV, CCo O-44, f. 107r-v). El 7 de junio de 1481, «Ioannes Ram, generosus, consiliarius serenissimi domini regis et pro eadem maiestate magister rationalis», operaba con un censo procedente de la herencia de Joan de Montpalau, «cum expressis licentia et voluntate magnifficorum Salellis de Monpalau, Francisci de Monpalau, militum, Manuelis de Monpalau, generosi, et Sicilie de Monpalau, domicelle, inferius laudantium et firmantium» (AMV, Protocols, Jaume Ximeno, t-13, s. fol.).

33 En 1482, siendo consejero del rey y maestre racional del reino de Valencia, Ram y su esposa cancelaban censos con la aprobación de los hermanos de ésta, Salelles, Francesc y Manuel de Montpalau, cuyas firmas figuran depués de las de «Ioannis Ram et Beatricis» (AMV, Protocols. Jaume Ximeno $\mathrm{t}-14$, s. fol.; 1482, mayo, 13). 


\section{Los inicios de una carrera política: la alcaidía de Morella}

Joan Escrivà era nieto de Manfré Escrivà, un prohombre de cierta relevancia en la Valencia de comienzos del siglo XV, a la que en 1401 representó como embajador (missatger) en la corte de Martín el Humano. ${ }^{34}$ En mayo de 1412, tras haber cambiado su apellido por el de Romaní, fue elegido conseller por los cavallers o generosos, ${ }^{35}$ lo que pone de manifiesto su pertenencia a la pequeña nobleza urbana. El 30 de junio de ese año, cuando llegó a Valencia la noticia de la sentencia de Caspe, «En Mamfré de Romaní, alias Scrivà», fue uno de los regidores municipales que se reunieron de inmediato en la cambra del consell secret. ${ }^{36}$ Era antiurgelista notorio. Poco antes, el día 10 del mismo mes, había solicitado del consell que fuesen castigados los responsables de los muchos y grandes «maleficis» que se hacían en la ciudad, ${ }^{37}$ en clara alusión a las acciones clandestinas de los partidarios del Dissortat, quienes, tras la derrota del Codolar (27 de febrero de 1412), perdieron el control político de la capital del reino, que había sido suya desde los comienzos del Interregno hasta esa batalla (Rubio Vela 2003: 214-216). La llegada al trono de Fernando I lo encumbró políticamente. El 10 de junio del año 1413, víspera de Pentecostés, «Mamfré de Romaní, alias Scrivà, donzell», era elegido uno de los dos jurats cavallers o generosos (Rubio Vela 2003: 217), y pocos meses más tarde fue nombrado, junto con otros seis ediles, para representar a la ciudad de Valencia en los actos de coronación de Fernando. ${ }^{38}$ En diciembre, a propuesta suya, Joan d'Aguilar, lugarteniente de protonotario del rey y prominente antiurgelista durante el Interregno, fue recompensado con cien florines por el gobierno municipal, en atención a sus desvelos en la corte en favor de la ciudad (Rubio Vela 2001: 216-217).

Manfré tuvo dos hijos varones con su primera esposa, Elionor Saranyó, fallecida hacia 1405 (Parisi 20082009: 60), Ximén Pérez de Romaní, alias Escrivà, y Manuel, que murió hacia 1426. Fruto de sus segundas nupcias con Iolant Torrelles fueron Jaume Escrivà, Mateu e Isabel. Todos quedaron bajo tutela de Iolant cuando Manfré falleció, también en $1426 .{ }^{39}$ La viuda, citada en la documentación como «la honorable dona Yolant, muller de l'honorable En Manfré de Romaní, donzell», y como «madona Yolant, muller

\footnotetext{
34 AMV, $L M$ 7, ff. 241r-242r (1401, diciembre, 31).

35 AMV, MC 25, ff. 46v-47r (1412, mayo, 30).

36 AMV, MC 25, f. 71 r.

37 «Més avant, fon exposat en lo present consell per l'onorable En Mamfré de Romaní, alias Scrivà, habitador de la dita ciutat, que per lo dit consell fos proveït a molts e grans maleficis que 's faÿen en la ciutat, e senyaladament al foch que en la nit passada fon assajat metre en l'obrador d'En Bernat Ponç, draper de la dita ciutat. E lo dit consell, veent que açò era cosa molt greu e de mal exemple, e de què s poria seguir gran dan e scàndel en la dita ciutat, provehí que lo justícia en criminal reebés informació secretament e pregà a aquell, com fos aquí present, que y entengués ab gran diligència e sàviament, e si era atrobat qui mes lo dit foch, que sia punit greument e haja pena corporal» (AMV, MC 25, f. 55v; 1412, junio, 10).
}

38 AMV, MC 25, f. 305v (1413, diciembre, 12). Véase Narbona Vizcaíno 1991: 89.

39 «... $\mathrm{a}$ N Jacme Scrivà, pubil, fill de l'honorable En Manfré de Romaní, donzell, quondam habitant de la dita ciutat, e per ell a la honorable dona Na Yolant Torrelles, muller del dit deffunct, mare, tudriu e curadriu d'aquell...» (AMV, Claveria Censal [CCe] I-53, ff. 48v-49r: 1435, octubre, 17; id., CCe I-54, f. 41v: 1437, octubre, 25); «al[s] honorables En Jacme Scrivà e N’Eximén Pérez de Romaní alias Scrivà, frares, donzells, habitadors de València, ab ferma consentiment e voluntat de la honorable dona $\mathrm{Na}$ Violant Torrelles, mare del dit En Jacme Scrivà, muller en segones núbcies de l'honorable En Mamfré de Romaní, donzell, quondam habitador de València, pare dels damunt dits En Jacme e Eximén Péreç [...]; al damunt dit En Manfré de Romaní, alias Scrivà, pare dels dits En Jacme e Eximén Péreç, és saber, a ell, tant com tocava lo usufruyt e tant com tocava la proprietat, axí com a pare e legíttim administrador del damunt dit N'Eximén Péreç Scrivà e En Manuel, frare seu, pubills, fills del dit En Mamfré e hereus de la honorable dona $\mathrm{Na}$ Elionor, primera muller sua, mare dels dits Eximén Péreç e Manuel [...]; dels quals dos hereus, és saber, lo dit Eximén Péreç Scrivà e Manuel, germans, lo dit Manuel passà d'aquesta present vida [...]; entre lo dit N’Eximén Péreç de Romaní, de una part, e la dita dona Na Violant, muller del damunt dit Mamfré de Romaní, en nom seu propri e encara axí com a usufructuària en los béns e drets per lo dit En Mamfré de Romaní, marit seu, lexats al dit Jacme Scrivà, frare del dit Eximén Péreç e fill de la dita dona, e encara axí com a tudriu e curadriu del dit En Jacme e Isabel, fills del dit En Mamfré e de la dita dona Na Violant» (id., QC W-4, ff. 22r-23r). El testamento de Manfré Escrivà fue redactado en Valencia el 30 de diciembre de 1426, según Parisi (2008-2009: 58-59), que aporta noticias acerca de su vida. 
de l'honorable En Manfré de Romaní, alias Scrivà, donzell», vivió treinta años más, pues consta que su testamento, confeccionado en 1453 , fue publicado en $1456 .{ }^{40}$

La vinculación de los Escrivà con la familia Ram, originaria de Morella, se debió al matrimonio del primogénito de Manfré, Ximén Pérez de Romaní, alias Escrivà, con Beatriu, hija y hermana, respectivamente, de los protonotarios reales Pere y Ferrer Ram. La proximidad de éstos a los Trastámara desde su entronización en la Corona de Aragón es notoria. También lo es la contribución activa del linaje morellano al éxito de la candidatura de Fernando de Antequera. Recordemos que el entonces obispo de Huesca, Domingo Ram más tarde arzobispo de Tarragona y cardenal—, fue uno de los compromisarios que en Caspe votaron en favor de Fernando (Segura y Barreda 1868: II 34-35, 38, 40-42, III 92).

No es de extrañar, dada la confluencia de dos familias tan afectas a la dinastía, ${ }^{41}$ que el joven Joan Ram y su hermano mayor emprendiesen con éxito una carrera política más allá del ámbito municipal, al servicio de la Corona. En el caso de nuestro poeta, es bien significativo que diera los primeros pasos en esa dirección en 1462, inmediatamente después de haber sido reconocido como heredero de su tío. Pasos iniciales que tuvieron como objetivo la alcaidía del castillo de Morella, y que no dieron fruto inmediato, tal vez porque los tiempos de Juan II eran bien distintos a los de su hermano el Magnánimo, al que Ferrer Ram sirvió en Nápoles como protonotario.

La alcaidía morellana estuvo en el siglo XV asociada a la familia Ram, con residencia en la villa, hasta que, «estinguida la línea de varon pasó á la casa de los Escrivans de Valencia». Con estas palabras, el historiador local Segura y Barreda (1868: I, 125) se refirió a la llegada a este oficio de Joan Ram, que situó equivocadamente en 1490. Hoy sabemos, además de que accedió a él mucho antes, que fue un premio a su actuación militar en la guerra civil catalana, en la que luchó desde 1472 en las filas del ejército realista. Apresado en una emboscada, sufrió cautiverio durante cuatro meses en el castillo de Perpiñán. Fue entonces cuando Juan II, como recompensa, lo nombró alcaide del castillo de Morella en un documento expedido en Tortosa el 23 de noviembre de 1476 según señaló Martí de Viciana (Riquer 1993: 90; Iborra 2013: 382).

No le fue fácil conseguir el nombramiento, al que aspiraba desde 1462. La continuidad de los Ram en la alcaidía - convertida en título de honor - se vio seriamente amenazada ese año, pues Juan II nombró alcaide de Morella a Rodrigo de Rebolledo, uno de los hombres de su máxima confianza. Ello significaba privar del título y oficio a la familia que lo venía detentando desde hacía más de medio siglo y, concretamente, a quien lo pretendía para sí: Joan Ram. Efectivamente, en una epístola fechada en septiembre de 1462, los jurats de la capital, siempre contrarios a que la nobleza foránea desalojase a la autóctona en oficios y beneficios de todo tipo (eclesiásticos, militares, políticos) en el reino, expresaban al rey su oposición al nombramiento de mossén Rodrigo de Rebolledo como alcaide, y pedían que el cargo fuese para «Johan Ram, donzell, fill de Eximén Pérez Scrivà». Alegaban que un extranjero no podía ostentarlo legalmente, pues, en virtud de un privilegio concedido por Juan I en 1393 a la villa, «la alcaydia del castell, e encara batlia de la dita vila e aldees d'aquella» habían de concederse «de necessitat a habitadors e no stranys de la dita vila»; además, el nombramiento violaría la propia legislación foral: «majorment que, encara per furs del regne seria e és prohibit lo dit mossén Rebolledo haver semblant offici, puix no és natural del present regne, del qual e de nosaltres és gran interés que lo dit fur sia observat». Por el contrario, Joan Ram, sería el hombre idóneo para el cargo, pues «és sufficientment heretat

$40 \mathrm{AMV}$, QC W-6, ff. $113 \mathrm{v}$ y $117 \mathrm{v}$.

41 Bien elocuente resulta al respecto el que en 1446 Juan de Navarra encomendara «el cargo de justicia [de Morella] por el trienio siguiente a Eximen Pérez de Romaní (a) Escrivà», según leemos en López Rodríguez (2005: 292), quien se refiere a él como «un forastero» en esa villa. 
en la dita vila e poria esser dit habitant en aquella, persona destra, abta, leal e molt sufficient al dit offici, e tots los seus predecessors han acostumat obtenir aquella». Además, «és tal persona e axí dotada, pertinent e molt devota a vostre servey, que sabrà donar bon compte e rahó a vostra senyoria e a la dita vila». ${ }^{42}$

Pocos días más tarde, el 13 de septiembre, llegaban a Valencia dos enviados de la villa y aldeas de Morella con el objetivo de informar de su posición sobre el asunto a los regidores de la capital del reino (doc. núm. 4 del apéndice). Fruto de esa gestión fue una nueva epístola de éstos al rey en la que le fueron expuestas las demandas de los morellanos, quienes, esgrimiendo sus privilegios, consideraban nulo el nombramiento de Rebolledo y pedían para sí la custodia: «la dita vila e aldees pretenen e desigen sumament que la custòdia del dit castell pot e deu esser a ells donada e acomanada, e no a altra persona alguna strangera» (doc. núm. 5 del apéndice). No se mencionaba en la misiva a Joan Ram, que,no obstante, volverá a aparecer en otras dos escritas el mes siguiente, una para el rey y otra para Rebolledo (doc. núm. 6 del apéndice). El contenido de ambas indica que la posición de los ediles valencianos se mantenía inalterable en lo relativo al castillo de Morella, «lo qual és una insigne força e clau de vostre regne de València». Señalaban que carecía de las armas, hombres y alimentos necesarios para su defensa, lo cual era peligroso, «attés lo temps occorrent e lo vehinat que té de Alcanyiç e de la frontera de Cathalunya, que ab poch esforç de gent d'armes poria ésser pres lo dit castell, ço que seria poch servey de vostra magestat e total destrució de tot lo regne de València». Y a continuación abordaban la concesión de la alcaidía a Rebolledo, «lo qual, per privilegi atorgat a la dita vila, no pot ni deu haver lo dit offici, e açò dóna gran entrenyor als hòmens de la dita vila, als quals, segons lo dit privilegi, pertany lo dit offici». Los de Morella apoyarían a Ram, según los ediles: «voldrien que lo dit offici recaygués en home habitador de la dita vila, axí com és En Johan Ram, donzell, lo qual té casa e habitador e moltes altres heretats en la dita vila». Ellos también eran partidario de este nombramiento porque, además de ser «conforme al dit privilegi e a la voluntat de la dita vila», recaería en persona idéonea: «lo dit En Johan Ram, ab sos parents e amichs, e ab la bona disposició de aquell, ha potència e manera de observar e guardar aquell castell». Finalmente, pedían al soberano que, «hagudes per revocades les provisions fetes al dit mossén Rebolledo del dit offici», nombrase alcaide a Ram, o bien que le encomendase la custodia del castillo hasta tomar una decisión definitiva — para lo cual debería de tener en cuenta el parecer de los de la villa—, y dar órdenes para que se le pagara el salario correspondiente. ${ }^{43}$

Un año después, el problema persistía. El 16 de junio, los ediles escribían «al molt noble e magníffich mossènyer e de gran saviesa mossén Rodrigo de Rebolledo, conseller e camarlench de la magestat del senyor rey», para pedirle que renunciara a la gracia real «de l'alcaydiat de Morella», argumentando nuevamente que el nombramiento era contrario a los privilegios de la villa. Hacían la petición junto a esta otra, a instancias de Morella: «consentir que 1 magníffich En Johan Ram, fill de N'Eximén Pérez Scrivà, haja la dita gràcia del dit senyor, per quant és molt aparentat e heretat en la dita vila, segons vol lo privilegi e molt dispost al dit offici». El mismo día se dirigían al rey en términos similares: «E per quant En Johan Ram, donzell, fill d'En Eximén Pérez Scrivà, té gran part de la sua parentela e heretat e casa en la dita vila e és accepte, per sa bona virtut e disposició, als hòmens de la dita vila e ab sos parents e amichs, e, ab la bona disposició sua, ha manera de conservar e guardar aquell castell com han fet sos antecessors en servey de la corona d'Aragó, segons som certs sab vostra excel lència, supplicam, per tal, aquella, axí humil com podem, per tots los dits respectes sia mercé vostra voler donar e atorgar lo dit offici al dit En Johan Ram, ab tots los salaris e preheminències de aquell, crehent vostra magestat ne serà servida» (Gual Camarena 1952: 506-507).

42 AMV, LM 25, ff. 111v-112r (1462, septiembre, 6).

43 Una misiva de los ediles valencianos a sus colegas de Morella indica la buena relación de Joan Ram con ambos: «La dita vostra letra reebem per mans del magníffich En Johan Ram, lo qual ab molta diligència ha treballat en tots los affers d'aquexa» (AMV, LM 25, f. 133v-134r; 1462, noviembre, 6). 
Si la insistencia de la ciudad en la resolución de un asunto fuera indicio de su importancia objetiva, parece evidente que el de la alcaidía de Morella no era irrelevante. En noviembre de 1463, los jurats enviaban a la corte como embajador al jurista misser Francesc Tallada, «un dels advocats ordinaris d'aquesta ciutat», encomendándole que tratara directamente la cuestión. Informaron por ello de su llegada a Rodrigo de Rebolledo, a quien, de manera sutil, expresaban su queja por no haber dado respuesta a las cartas que le habían enviado al respecto. Sin resultado positivo, a juzgar por lo que en abril del año siguiente escribían al rey y a la reina, sin ocultar su disgusto: «Per diverses letres e misatgers nostres e d'aquesta ciutat havem scrit e suplicat a vostra excel lència fos mercé vostra que lo alcaydiat del castell de la vila de Morella fos donat per vostra senyoria a home natural e habitador de la dita vila, segons disposició de privilegis e constitucions reals atorgades a aquella, e no volgués permetre que lo noble mossén Rodrigo de Rebolledo, al qual se deÿa era stat proveÿt per vostra serenitat de la dita alcaydia passàs a aquella». No menor era el rechazo que provocaba en los regidores de Morella, a quienes los de la capital aconsejaban dos días antes impugnar un nombramiento contrario a sus privilegios, «al legant, entre les altres coses, que lo mossén Rodrigo de Rebolledo no és natural d'aquest regne e, per consegüent, no pot impetrar obtenir ni possehir offici o beneffici en aquell» (Gual Camarena: 1950-51: 190-191; 1952: 508-513).

\section{El patriciado y el entorno de Juan II.}

Por estas fechas, el patriciado de Valencia ya se había decantado claramente en favor de Juan II en su confrontación, ya comenzada, con el principado de Cataluña. Lo cual no quiere decir que los prohombres valencianos permanecieran impasible ante a los actos y gestos autoritarios del monarca. Hoy sabemos que el gobierno de la capital del reino no sólo no cedió a las presiones reales cuando estalló el conflicto con el príncipe de Viana —hasta el momento mismo de su muerte fue considerado y titulado primogénito por los ediles, contrariando al padre-, sino que reiteradamente instó a éste a reconocerlo como legítimo heredero y sucesor (Rubio Vela 2013: 594-602). Sabemos igualmente que la oligarquía valenciana se mostró disconforme, y no sólo de palabra, con los excesivos favores del soberano a los nobles castellanos que se exiliaron a la Corona de Aragón por haber defendido sus intereses en el reino vecino. Tal es el caso del conde de Castro y Dénia, ya estudiado (Rubio Vela 2010: 31-39 y 49-66), al que hay que sumar el de otro desterrado de Castilla por haber servido al entonces Juan de Navarra: Rodrigo de Rebolledo. Citado en el Dietari del Capellà como «criat del rey» (Rodrigo Lizondo 2013: 286), fue recompensado por éste, con el nombramiento de camarero mayor y con señoríos y rentas en Aragón, Cataluña y reino de Valencia. ${ }^{44}$ La alcaidía de Morella fue uno de esos favores reales. En ese contexto hay que situar la difícil lucha de Joan Ram para conseguirla y el apoyo que tuvo de la oligarquía autóctona.

El 14 de febrero de 1466, entre las peticiones presentados a Juan II por el brazo real en las cortes de Sant Mateu, figuraba la anulación de la concesión a Rebolledo, formulada con los argumentos ya conocidos (Gual Camarena 1952: 514-515). Y, siete días después, el 21, el brazo militar, presentaba un greuge alusivo

44 Blasco de Lanuza 1622: 126-127; López Rodríguez 2005: 81. Ya la Crónica del Halconero de Juan II alude a la privanza: «Rodrigo de Robolledo, pribado del rrey de Nauarra» (Carriazo 1946: 399). Le sigue Zurita en los Anales (libro XIV, cap. LVIII): «que era un caballero muy privado del rey de Navarra» (Canellas 1980: 206). El historiador aragonés puso en su boca estas palabras (libro XV, cap. XLI): «jCómo queredes vos, señor, que yo yerre al rey de Navarra que me crió!» (Canellas 1980: 359). Y en el relato de la batalla naval de Ponza (libro XIV, cap. XXVII): «fue cosa muy cierta y sabida que el rey de Navarra fuera muerto en la batalla si no se hallara a su lado un caballero de su casa, natural del reino de Castilla, de Castrojeriz, que desde su niñez le siguió y sirvió siempre, que fue muy valiente y señalado capitán y de los muy valerosos que hubo en sus tiempos y se llamó Rodrigo de Rebolledo». Unas líneas después sitúa entre los «muy principales señores que fueron prisioneros»a «Rodrigo de Rebolledo, que se rindió juntamente con el rey de Navarra» (Canellas 1980: 94-95). En el capítulo XIII del libro VI de la Segunda Década, Escolano (1611: 103-104), al referirse al «noble linaje de los Rebolledos», afirma que el más señalado de sus varones, «don Rodrigo Rebolledo [...], fue Camarero mayor del Rey Don Iuan $[\ldots]$ y muy su priuado». 
a la concesión de oficios del reino a forasteros, y concretamente las alcaidías de los «castells del Poyo, de la vila de Morella e de Alacant» a Rodrigo de Rebolledo y a Alfonso de Rebolledo. ${ }^{45}$ Dada la pertenencia de Joan Ram, aspirante a la de Morella, al estamento militar, y el apoyo de que gozaba en el gobierno de la capital del reino, no es de extrañar ambas solicitudes, para las que el monarca tenía fácil respuesta, ya que veinte años atrás, en 1446, por iniciativa suya, cuando era lugarteniente general de su hermano Alfonso, Rodrigo de Rebolledo fue habilitado como natural del reino de Valencia por las cortes. ${ }^{46}$ De ahí que en 1461 los jurats, a propósito de un problema similar planteado por los regidores de Alpuente en relación con la alcaidía del castillo del Poyo, escribieran: «Som, emperò, informats per lo dit magníffich mossén lo batle general que lo dit alcaydiu és de mossén Rodrigo de Rebolledo, oncle del dit Alfonso, qui és per fur abilitat e pot posseyr officis e benefficis en aquest regne, e a ell o procurador seu tro ací ha fets pagaments del salari del dit alcaydiu». ${ }^{47} \mathrm{La}$ habilitación fue otra de las multiples pruebas de afecto hacia Rebolledo, militar «de la confianza del infante don Juan» (Riquer 1994: 61), hacia el «fiel camarlengo» que Vicens Vives incluye entre los «juanistas convencidos» cuando dio comienzo la crisis del reinado (2006: 76 y 140).

El monarca, a pesar del rechazo que suscitó entre las oligarquías valencianas el nombramiento de Rebolledo como alcaide de Morella, se mantuvo firme. En 1468, debido a la ausencia del noble, que cayó prisionero de los rebeldes catalanes el año anterior, se mostró dispuesto a encomendar la custodia del castillo a «En Joan Ram Scrivà, donzell de la dita vila», pero provisionalmente, hasta que él, «ab voluntat de mossén Rebolledo, haja feta provisió de la dita castellania»; lo que significaba, en palabras de Gual Camarena, que accede al « nombramiento de Juan Ram como alcaide, pero a la vez deja bien sentados los principios de su autoridad [...] y el derecho preferente de Rodrigo de Rebolledo» (1952: 502-503 y 516-519). Solamente en 1476, catorce años después del comienzo de este asunto, Juan II concedió a Ram, con carácter definitivo, el oficio que su linaje materno había ostentado desde los comienzos del siglo. Y lo hizo, según vimos, para premiar una actuación militar. Queda patente, pues, la prolongada resistencia del soberano a privar del cargo a su camarlengo. No menos patente que la persistencia del patriciado en reclamarla para el joven doncel desde 1462, el año en que su vida daba un giro radical. Una actitud que pone de manifiesto la existencia de dos sectores políticos con intereses distintos entre los valencianos que apoyaban al monarca que hacía frente a la insurrección del principado, y que el gobierno de la capital estaba en manos de uno de ellos, el mayoritario, hostil a la excesiva influencia de los castellanos exiliados del entorno real.

\section{Observaciones finales sobre onomástica y cronología}

Los nombres que el protagonista de estas páginas tuvo a lo largo de su vida guardan cierta secuencia. Según se habrá podido comprobar en páginas anteriores, primero se llamó «Joan Escrivà» y, desde finales de 1461, «Joan Ram». Cambió de apellido, pues, y por ello en los años siguientes al cambio se suele precisar en los textos: «Joan Ram olim Escrivà»o «Joan Ram alias Escrivà». Acabó siendo «Joan Ram Escrivà». Así figurará desde la década de los setenta, con ambos apellidos, el materno seguido del paterno, sin términos latinos interpuestos (Cruselles 1989: 152, 161, 215, 228-241, 244-260).

45 AMV, Processos de Corts, yy-22, f. 103r.

46«Et hiis ita peractis, dictus dominus rex locumtenens generalis promulgavit, de voluntate et consensu totius curie et trium brachiorum ipsius, actum curie continentie subsequentis: Lo senyor rey, lochtinent general, etc., ab consentiment e voluntat de la present cort, habilità la persona de mossén Rodrigo de Rebolledo, cavaller, enaxí que d'ací avant sia haüd, reputat e tractat en totes coses per natural e habitador del regne de València, enaxí que, consultat lo senyor rey, si a aquell plaurà, que axí passe que nunc pro tunc lo dit mossén Rebolledo sia haüd per natural e habitador del regne» (AMV, Processos de Corts, yy-17, f. 391r; 1446, junio, 6).

47 AMV, LM 23, ff. 297v-298r (1461, marzo, 28).

SCRIP'TA, Revista internacional de literatura i cultura medieval i moderna, núm. 3 / juny 2014 / pp. 46-70

ISSN: 2340-4841 · doi:10.7203/SCRIPTA.3.3788 
En el año 1461, cuando adoptó el apellido Ram tras el hallazgo del testamento, había de tener veinte años como mínimo. En la época, para poder presentarse directamente ante notario, actuar ante la justicia como heredero u operar con los censos procedentes de una herencia, como él hizo, había que acreditar ser mayor de edad. Y esto significaba haber cumplido los veinte años, según demuestran reiteradamente textos en los que se hacía constar esa circunstancia, ${ }^{48}$ conditio sine qua non para que una herencia se hiciera efectiva, ${ }^{49}$ o para realizar actos jurídicos. ${ }^{50}$ Solamente en caso de haber recibido una dispensa expresa de la máxima autoridad, un menor de veinte años podía proceder como mayor. ${ }^{51}$ No parece que fuera este el caso del joven poeta, cuya fecha de nacimiento no se conoce, pero que podría situarse hacia 1438, después de la de su hermano Ximén, que Parisi sitúa «vers 1435» (2008-2009: 60). Si así fuera, estaríamos ante un niño de unos diez años años cuando su tío hizo testamento en Nápoles, y ante un joven de unos veintitrés cuando consiguió la herencia.

Nada tiene de extraño que su nombre de pila aparezca en diminutivo en la época aquí estudiada: «Johanot Scrivà e ara se appella Johanot Ram», dice el más temprano de los documentos en que se le cita, del año 1462 (apéndice, doc. núm. 2). En 1464, los jurats de Valencia, en carta a Morella, escribían: «De aquesta matèria se'n va pus plenament informat lo magnífich En Johanot Ram, al qual sobre açò en tot lo que us dirà podeu donar plenera fe e crehença» (Gual Camarena: 1952: 514), y el clavari registraba en su libro de cuentas un pago «a l'honorable En Johanot Ram, donzell, habitador de la dita ciutat» (apéndice, doc. núm. 7). También se escribe así en 1465, en la relación de donceles convocados a las cortes, donde dice: «Dilecto nostro Ioannoto Ram, alias Scrivà, domicello». ${ }^{52}$ Y en 1469 , cuando el notario Jaume Gisquerol levantó acta de un espectáculo caballeresco que tuvo lugar el primer día de octubre de ese año, registró entre los presentes a un caballero «mossèn Joan Escrivá, alias Çanoguera», que actuó como padrino de uno de los contendientes, y a nuestro doncel «Joanot Ram, alias Escrivà» (Hinojosa Montalvo 2013: 221-222). La homonimia con su pariente pudo ser uno de los motivos del diminutivo diferenciador, que todavía en 1477 se le aplica en una relación de «militars sense heretats» en la que aparece «Joanot Ram» inmediatamente después de los Montpalau y de su hermano Ximén (Llorca s. d.: 84). Ahora bien, al igual que en el caso de Joanot Martorell — por entonces escribía el Tirant—, no se le aplicaba de manera sistemática, ${ }^{53}$ según demuestran

48 «lo dit En Berenguer Mercader, fill e hereu qui dessús, ha obtenguda edat de XX anys, segons se mostra per sentència lata en la cort civil» (id., CCo O-24, ff. 57v-60r, y CC J-62, f. 54v: 1448, marzo, 14); «al dit En Perot d'Arinyo, donzell, en lo XX any de la sua edat constituït» (id., CC J-63, f. 13r-14v; 1448, septiembre, 14); «ego Guillermus Mercader, generosus, filius magniffici Guillermi Mercader, quondam militis, habitator civitatis Valentie iam factus maior annorum viginti, ut constat...» (id., Protocols, Jaume Ximeno 8-4, ff. 102r-103r; 1472, mayo, 13).

49 «...leixà usufructuària de tots sos béns la dona N'Angelina, muller sua, tro Bernat, fill seu fos de edat de vint anys» (AMV, CCo O-24, ff.45v-48r; 1448, marzo, 14).

50 «És veritat que 1 dessús dit En Johan de Vilarasa ha obtenguda edat de XX anys e poder contractar e fer totes coses que majors de XX anys poden fer, administrar e contractar, e axí és estat pronunciat e declarat per l'onrat [...]... justícia civil [...] en procés de edat iniciat davant lo dis justícia» (AMV, CCo O-21, f. 35r; 1443, febrero, 18).

51 He aquí un ejemplo: «E jassia [...] fos constituït sots tutela e cura de l’honorable mossén Jacme de Tagamanent, cavaller [...], emperò, la molt alta senyora reyna dona Maria, com a lochtinent general del molt alt senyor rey, marit seu, de present gloriosament regnant, supplints a aquell lo deffalliment de la sua edat, en lo XVIIII any de la qual lo dit hereu era constituï, ha-li atorgat vènia de la dita edat, dispensant en aquella, donant a aquell licència que, no obstant lo dit deffalliment de edat, puxa ell e sos béns regir, tenir, administrar e en qualsevol manera dispensar o ordenar, segons per letra de la dita senyora a aquell atorgada, data Valentie XV $T^{a}$ die augusti anno a nativitate Domini $M^{\circ} C C C C^{\circ} X X X X^{\circ}$ » (AMV, $C C$ I-56, f. $\left.210 \mathrm{r}\right)$.

52 AMV, Processos de Corts, yy-22, f. 6v. Le precede su hermano: «Dilecto nostro Eximeno Pérez Scrivà, domicello».

53 Aprovecho para puntualizar lo escrito recientemente acerca del nombre de pila de Martorell por el profesor Furió (2013: 154 y 160), que considera equivocada — -no em sembla plausible»— la identificación del novelista con el caballero Joan Martorell, procurador general de los Rojas Sandoval en el condado de Dénia, propuesta por mí (Rubio Vela 2010). Aduce «que el procurador dels Rojas Sandoval sempre es diu Joan, mai Joanot», lo que 
Agustín Rubio Vela. Circunstancia familiar y entrada en la vida política del joven poeta valenciano Joan Escrivà (1461-1462)

instrumentos de 1462 en los que es citado como «Johan Ram, donzell» (apéndice, docs. núm. 3 y 8). El Joanot de estos años es la misma persona denominada, entonces y en tiempos posteriores Joan Ram, Joan Ram olim (o alias) Escrivà o Joan Ram Escrivà. Cuando ostenta cargos relevantes, el diminutivo desaparece. Los textos, en este caso, no dejan resquicio alguno para cuestionar lo obvio.

Tras el nombre se hacía constar su condición de doncel, algo habitual en unos tiempos en que el rango social formaba parte inseparable de la identidad (docs. núm. 3, 6 y 7). Quiere decir ello que había nacido en una familia del estamento militar, pero que no había alcanzado aún la condición de caballero; sólo era generós y no tenía tratamiento de mossén. Bastante más tarde fue elevado a la categoría de miles y recibiría dicho tratamiento. La primera referencia cronológica que hemos podido documentar de «mossén Johan Ram Scrivà, cavaller» está en el libro de quitaments del año 1481-82. ${ }^{54}$ Lo cual podría precisar algo la fecha de redacción del poema Cobles fetes per Mossèn Fenollar e per Mossèn Joan Escrivà, cavaller, contemplant en Jesucrist crucificat, editado en 1493 como Contemplació a Jesús crucificat feta per Mossén Johan Scrivà, mestre racional, e per Mossén Fenollar (Garcia Sempere 2002: 419-446), dado que se le cita con una titulación que no parece haber tenido antes de 1482, y que la obra ha de ser anterior a 1486, fecha del Jardinet d'Orats (Riquer 1993: 88).

Por otro lado, en el Parlament en la casa de Berenguer Mercader se le cita con el nombre que tenía antes de finales de 1461, cuando lo cambió tras el hallazgo del testamento. Efectivamente, Roís de Corella puso el mito de Orfeo y Eurídice en boca de su amigo Joan Escrivà, ${ }^{55}$ que lo recitaría con excelente verbo ante la admiración del resto de contertulios: «Axí havia transportat Johan Scrivà en la ben rahonada faula nostres entrestides penses, que a cascú de nosaltres semblava Eurídices havia perduda. E lo poder de la attenta imaginativa forçà a tots fer aquell gest que de Orpheu se rahonava, girant-nos a les spatles per veure si Eurídices venia» (Martos 2001: 250-260). El que en la obra se le llame Joan Escrivà, su nombre hasta 1461, y no Joan Ram, podría considerarse un dato de interés para establecer la cronología del Parlament, que, según Martí de Riquer, se redactó «en data encara no ben determinada», en cualquier caso «anterior al març del 1471» (1964: 315-316; 1993: 88), pero que Cingolani, atendiendo a consideraciones de estilo, afirma que hubo de ser escrito antes de 1460 (1998: 25). Ahora bien, aunque desde una perspectiva documental no cabe poner reparo alguno a esta última hipótesis, el argumento onomástico dista de ser prueba concluyente de terminus ante quem para las prosas mitológicas corellianas, ya que el autor siguió usando el primero de sus nombres con posterioridad a 1461, como demuestra el Jardinet, texto fechado un cuarto de siglo después, en el que hay cuatro piezas suyas, donde aparece con el tratamiento de mossén precediendo al primero de sus nombres, y con la condición de caballero: «mossén Joan Escrivà, cavaller» (Riquer 1964: 354-355; y 1993: 87-88).

\footnotetext{
considera «fet prou concloent», e insiste: «de fet, com ja ha observat Mateu Rodrigo, mai no és anomenat Joanot, quan a l'autor del Tirant se li dóna aquest nom en tot el corpus documental reunit per Villalmanzo i Chiner, fins i tot després de la seva mort». No es preciso demostrar, por ser obvio y comprobable, que Martorell, en el corpus documental citado, figura como Joanot y como Joan, y que como Joan no aparece excepcionalmente o de manera ocasional, sino en el veinticinco por ciento de los casos, según el recuento hecho por Ferrando (2012: 652), lo que quiere decir que en una de cada cuatro menciones documentales el nombre de pila del escritor no figura en diminutivo. Ocultar esto puede dar apariencia de fuerza a un argumento débil, pero a costa de enmascarar la realidad.
}

54 Véase nota núm. 31.

$55 \mathrm{La}$ amistad persistió. Muy significativo resulta, a nuestro juicio, el hecho de que el 21 de noviembre de 1482, en el acto por el que el gobierno municipal de Valencia acordó pagar un salario anual de mil sueldos a Corella por las lecturas sobre los Evangelios que hacía en la casa consistorial, se hiciera presente como testigo «En Joan Ram Scrivà, mestre racional de la cort del senyor rey» (Torre 1926: 108, donde equivocadamente aparece así: «en Joan Ram, scriua»). 
Agustín Rubio Vela. Circunstancia familiar y entrada en la vida política del joven poeta valenciano Joan Escrivà (1461-1462)

\section{Documentos}

1458, mayo, 23.- Valencia.

El clavari dels censals de la ciudad de Valencia cancela un censo que habia sido comprado en 1448 por el jurista Ferrer Ram y que, tras la muerte abintestato de éste, heredó su hermana Beatriu, quien lo vendió en 1456 al mercader Manuel Vives, perceptor de su valor monetario.

-AMV, QC W-5, ff. 163r-164r.

Primerament, paguí e doní a l'honrat En Manuel Vives, mercader, ciutadà de València, set mília siscents cinquanta cinch sous, set diners, de moneda reyals de València, és saber: $\mathrm{VII}^{\mathrm{m}} \mathrm{D}$ sous per preu o quitament de aquells $\mathrm{D}$ sous de la sobredita moneda, censals, rendals e annuals, los quals en dies passats per lo honrat e discret En Johan Marromà, notari, ciutadà e síndich de la dita ciutat, foren venuts e originalment carregats sobre los béns e drets de la universitat de la dita ciutat a l'honorable micer Ferrer Ram, doctor en leys, conseller e prothonotari del senyor rey, e als seus, pagadors cascun any a XXVIII de janer en una solució o paga, ab carta de venda e carregament feta en València en poder del notari davall scrit a VI de maig de l'any de la nativitat de nostre Senyor mil CCCCXXXXVIII. Enaprés lo dit honorable micer Ferrer Ram morí sens haver fet testament e succehí en los seus béns la honorable dona Na Beatriu, germana sua, muller de l'honorable N'Eximén Pérez de Romaní alias Scrivà, donzell, habitador de la ciutat de València, segons de la dita successió consta per sentència lata per lo honorable justícia civil de la dita ciutat a XVIII de janer de l'any de la nativitat de nostre Senyor mil CCCCXXXXVIIII, closa e subsignada de la mà del discret En Pere Navarro, notari, altre dels scrivans de la cort civil de la dita ciutat. E finalment lo dit N'Eximén Pérez Scrivà e la dona $\mathrm{Na} \mathrm{Be}[\mathrm{a}]$ triu, muller de aquell, e encara lo honorable N'Eximén Pérez de Romaní Scrivà, donzell, fil[] dels sobredits cònjuges, veneren e alienaren los dits D sous censals al sobredit En Manuel Vives e als seus, ab tots sos drets, segons consta ab carta pública feta en València a VI del mes de noembre de l'any mil CCCCLVI, rebuda per lo discret En Manuel Sparça, notari. E, d'altra part, li paguí e doní cent cinquanta cinch sous, set diners de la sobredita moneda per pensió prorata del dit censal, comptada de tres meses vint dos dies, finits lo XXén dia del present mes de maig, en lo qual dia fon fet lo dit quitament. E ha-n’i carta de quitament rebuda per lo honrat e discret En Jacme Beneyto, notari e scrivà dels honorables jurats e consell de la ciutat de València, feta a XXIII de maig de l'any mil CCCCLVIII. Les quals dos partides, reduhides a compte de lliures, munten e prenen suma de trescentes huytanta dues lliures, quinze sous, set diners de la sobredita moneda: CCCLXXXII lliures, XV sous VII.

1462, febrero, 13.-Valencia.

Los jurats de Valencia piden a Juan II que intervenga para evitar las complicaciones judiciales que podrian afectar a compradores de rentas censales que fueron del jurista Ferrer Ram, que pasaron a su hermana Beatriu al creerse que habia muerto abintestato, pero que el hijo de ésta, Joanot Escrivà, que habia cambiado su nombre por el de Joanot Ram, demostró ser propietario legítimo tras haber descubierto, oculto en la casa paterna, el testamento de su tío, en el que lo declaraba heredero universal.

-AMV, $L M$ 25, f. 62r-v.

SCRIPTA, Revista internacional de literatura i cultura medieval i moderna, núm. 3 / juny 2014 / pp. 46-70 ISSN: 2340-4841 · doi:10.7203/SCRIPTA.3.3788 
Agustín Rubio Vela. Circunstancia familiar y entrada en la vida política del joven poeta valenciano Joan Escrivà (1461-1462)

A la sacra magestat de nostre senyor lo rey.

Sereníssimo senyor:

Aprés mort de micer Ferrer Ram, prothonotari del sereníssimo senyor rey don Alfonso, de gloriosa recordació, frare vostre, lo qual finà sos dies en lo realme de Nàpols, la dona $\mathrm{Na}$ Beatriu, germana sua, muller de N’Eximén Pérez Scrivà de Romaní, pretenent que lo dit micer Ferrer Ram era mort abintestat, obtengué del tunch justícia civil d'aquesta ciutat successió en tots los béns que foren del dit son germà, axí vinculats com altres. E com a hereva de aquell ha contractat e fets carregaments de censals sobre los béns del dit micer Ferrer, e en altra manera, fins ací. És-se seguit, senyor, que, aprés mort del dit Eximén Pérez Scrivà, un son fill apellat Johanot Scrivà, e ara se appella Johanot Ram, se diu que ha trobat en la casa del dit son pare, dins una caxa, un testament en pública forma del dit micer Ferrer, fet en Nàpols sots cert kalendari, sots signat de mans de nou testimonis ultra la clausura del notari que reebé e signá aquell, per lo qual se descobre que lo dit micer Ferrer, entre les altres coses, ha instituït hereu seu universal lo dit Johanot Ram, nebot seu. E axí, aquell, en virtut del dit testament, demana e requer esser mès en possesió de tots los béns e drets que foren del dit oncle seu. E ultra, perquè la dita mare sua, dient e demostrant esser hereva abintestat del dit micer Ferrer, germà seu, havia contractat ab moltes maneres de gents e fetes molts carregaments de censals e altres contractes sobre censals e béns del dit germà seu, ha fet intimar les dites coses, entre los altres, a mossén Loís Johan e Lorenç Johan, germans, e mossén Amigó, perquè aquells, contractants a bona fe e sana, crehían la dita $\mathrm{Na}$ Beatriu ésser verdadera hereva e successora en tots los béns del dit micer Ferrer Ram en virtut de la successió abintestat, feta e declarada per lo dit justícia civil, han comprat certs sensals e covinent suma de la dita dona, e aquella, en lo dit nom de hereva, los ha venuts e carregats specialment sobre béns e censals que foren del dit micer Ferrer Ram. E més avant, lo dit Johanot Ram ha fet emparar tots los béns e censals que foren del dit micer Ferrer. Seguides, senyor, les dites intimació e empara, los dits Johanes e mossén Amigó han demostrat d'aquella molt gran congoxa, e de ffet per la dita rahó aquells han denunciat la dita dona $\mathrm{Na}$ Beatriu davant lo lochtinent de governador e justícia criminal, per aquell a qui pertanga. Supplicam vostra magestat, axí homilment com podem, sia mercé vostra vullau scriure e manar ab imposició de grans penes als dits lochtinent de governador e justícia criminal e lochtinent de aquell que en collir la dita denunciació e tots los actes d'aquella se hagen ab suma cura e diligència, sens perdre un dia de dilació. E d'altra part, senyor, si era recorregut a vostra magestat per alguna de les dites parts, axí per la dita causa criminal com altra qualsevol civil, no vulla manar ni provehir cosa alguna per lo qual la dita denunciació justícia se pogués dilatar o empaxar, ans que molt prestament ne sia vista la justícia e veritat. E açò mateix, si serà mercé vostra, senyor, vulla manar als canceller, vicecanceller, prothonotari, secretari e scrivans vostres, a ffi que, avisats, no provehissen ni desempaxassen cosa alguna en contrari. E haurem ha singular gràcia e mercé de vostra excel lència, la qual nostre senyor Déus vulla longuament conservar ab molta exaltació de honor e glòria. Scrita en València, a XIII dies de febrer de l'any MCCCCLXII.

Senyor, de vostra magestat homills vasalls e servidors, qui ‘s recomanen en gràcia e mercé vostra, los jurats de València. 
Agustín Rubio Vela. Circunstancia familiar y entrada en la vida política del joven poeta valenciano Joan Escrivà (1461-1462)

1462, septiembre, 6.- Valencia.

Los jurats de Valencia, ante la noticia de que habia sido nombrado alcaide del castillo de Morella mossén Rodrigo de Rebolledo, no natural del reino, lo que sería contrario a un privilegio de 1393 concedido a la villa, así como a los Furs de Valencia, se dirigen a Juan II para que no biciera efectivo el nombramiento y piden el cargo para Joan Ram.

—AMV, LM 25, ff. 111v-112r.

Sereníssimo senyor.

Per statut e privilegi special del senyor rey don Johan, de gloriosa recordació, dat en València a X de jener de l'any MCCCLXXXXIII, atorgat als officials prohòmens e habitadors de la vila de Morella, havem vist que la alcaydia del castell, e encara batlia de la dita vila e aldees d'aquella, en cas de vacació, per mort o en altra manera, per certs bons respectes, han e deuen esser atorgades de necessitat a habitadors e no stranys de la dita vila. Dehim-ho, senyor, per tal que 's diu que vostra magestat hauria novament provehit de l'offici de la dita alcaydia, vacant per mort de l'últim detenidor d'aquella, a mossén Rodrigo de Rebolledo. E per bé, senyor, que lo dit mossén Rebolledo sia persona notable e meritant de moltes majors gràcies e favors, seria, emperò, senyor, cosa dura e incomportable que, contra tenor exprés del dit privilegi, persona alguna, de quanta dignitat e preheminència sia, obtingués lo dit offici per les rahons e consideracions bones, justes e rahonables en lo dit privilegi expresades, concernents grantment servey de vostra magestat e gran útil e beneffici de la dita vila e del dit castell, majorment que, encara, per furs del regne seria e és prohibit lo dit mossén Rebolledo haver semblant offici, puix no és natural del present regne, del qual e de nosaltres és gran interés que lo dit fur sia observat. Supplicam, per tal, vostra excel lència, axí homilment com podem, sia mercé vostra manar servar a la dita vila lo dit privilegi antich, e contra tenor d'aquell no vullau proveyr cosa alguna, segons de vostra celsitut indubitadament s'espera ab gran confiança. E perquè, senyor, som informats que los officials, vehins e habitadors de la dita vila seríem (sic) molt contents que obtingués lo dit offici de alcaydia En Johan Ram, donzell, fill de Eximen Pérez Scrivà, lo qual és sufficientment heretat en la dita vila e poria esser dit habitant en aquella, persona destra, abta, leal e molt sufficient al dit offici, e tots los seus predecessors han acostumat obtenir aquella, haurem-ho, senyor, a molta e assenyalada gràcia de vostra magestat, vulla proveyr del dit offici al dit En Johan Ram ab lo salari e preheminències acostumades. Lo qual és tal persona e axí dotada, pertinent e molt devota a vostre servey, que sabrà donar bon compte e rahó a vostra senyoria e a la dita vila. Nostre senyor Déus, per sa infinida clemència, vulla longament conservar vostre real stat e persona ab molta exaltació de honor e glòria. Scrita en València a VI dies de setembre de l’any MCCCCLXII.

Senyor, de vostra magestat homils vassalls e servidors, qui ‘s comanen en gràcia e mercé vostra, los jurats de València.

1462, septiembre, 22.- Valencia.

Los ediles de Valencia aseguran a los de Morella que actuarán en apoyo de sus demandas, de las que habian sido informados verbalmente por Joan Allepucy Joan Tàrrega, enviados por la villa y sus aldeas.

-AMV, $L M$ 25, f. 113 r.

SCRIPTA, Revista internacional de literatura i cultura medieval i moderna, núm. 3 / juny 2014 / pp. 46-70

ISSN: 2340-4841 · doi:10.7203/SCRIPTA.3.3788 
Agustín Rubio Vela. Circunstancia familiar y entrada en la vida política del joven poeta valenciano Joan Escrivà (1461-1462)

\begin{abstract}
Als molt honorables e savis senyors los justícia, jurats e prohòmens de l'ajust de la vila e aldees de Morella.

Molt honorables e savis senyors: Vostra letra de XIII del present mes havem reebut, ab creença explicadora per los honorables En Johan Allepuç e En Johan Tàrrega, missatgers vostres, e havem oÿt a ple tot ço que dir e explicar nos han volgut de part de vostres saviesses. Responem-vos que, a totes les coses per aquells a nosaltres dites narrades, havem fet nostra resposta e dita nostra voluntat als dits vostres missatgers, segons per llur relació poreu esser largament informats. Podeu esser, senyors molt honorables, esser certs que tota hora nosaltres, en tot lo que ns serà possible, entendrem e treballarem ab molta bona voluntat per tot nostre poder en lo benavenir, beneffici e repòs de aquexa vila e aldeyes. $\mathrm{Si}$ altres coses, molt honorables e savis senyors, vos seran plasents de nosaltres, serem contents nos ne aviseu. E tinga-us en sa guarda la Sancta Trinitat. Scrita en València a XXII dies de setembre de l'any MCCCCLXII.
\end{abstract}

Los jurats de València, a honor vostra apparellats.

1462, septiembre, 22.- Valencia.

El gobierno municipal valenciano, requerido por el de Morella, escribe de nuevo a Juan II para insistir en que Rodrigo de Rebolledo no puede ser legalmente alcaide del castillo de Morella, y le piden que el nombramiento se realice con arreglo a los privilegios concedidos a la villa por monarcas anteriores.

-AMV, $L M 25$, ff.113r-v.

Sereníssimo senyor:

Per certs missatgés a nosaltres tramesos per part de la vila e aldeyes de Morella som stats informats que, vacant la alcaydia e tenència del castell de la dita vila, vostra magestat ne hauria proveÿt a mossén Rodrigo de Rebolledo, en la qual provisió aquells affermen esser-los fet gran e evident prejuhí e greuge perquè pretenen que seria contra exprés privilegi e concessió special atorgat a la dita vila e pobladors d'aquella, ab molts grans fonaments, per lo senyor rey don Jacme, de gloriosa recordació, per lo qual, entre les altres coses, és dispost que lo dit castell ha esser comanat a cavaller o home de llur creció e casa, o a ells, si ho voldran, serà donat a custòdia, e no a altra persona vinent; e seria, encara, contra tenor d'altre privilegi special del senyor rey don Johan, d'alta recordació, dat en València a X de jener any MCCCLXXXXIII, statuint expressament que com s'esdevingués vacar los officis de l'alcaydia del castell e batlia de la dita vila per cessum o decessum de Bernat de Junyano, donzell, llavors tenint los dits officis a vida sua, o aprés quantsevulla, los dits officis no serien donats ensemps ni a una persona ni a altres sinó a habitadors de la dita vila, enaxí que, vaccants los dits officis per cessum o decessum del dit En Bernat Juyano, o enaprés quantsevulla o en qualsevol manera, no a una persona mas a dos, e no a stranys de la dita vila, mas a habitadors de aquella fossen donats, e no per altres persones ni per altra manera per algun o alguns los dits officis puxen esser regits e exercits, ni encara los jurats, prohòmens e universitat de la dita vila sien tenguts ni puxen esser compellits en altra manera admetre al regimen[t] dels dits officis algun o alguns. E si per ventura per alguns temps, per oblivió, importunitat $o$

SCRIPTA, Revista internacional de literatura i cultura medieval i moderna, núm. 3 / juny 2014 / pp. 46-70 ISSN: 2340-4841 · doi:10.7203/SCRIPTA.3.3788 
Agustín Rubio Vela. Circunstancia familiar y entrada en la vida política del joven poeta valenciano Joan Escrivà (1461-1462)

en altra guisa, scientment $\mathrm{o}$ ignorant era fet lo contrari, no hagués valor, ans freturàs de forces e effecte, $\mathrm{e}$ sens alguna revocació expressa del dit privilegi e vigor fos haüt lo contrari de tot en tot per revocat, segons totes aquestes coses e moltes altres apparen per tenor dels dits privilegis, molt favorables e specials. Per los quals, e paraules e concessions en aquells expressats, la dita vila e aldees pretenen e desigen sumament que la custòdia del dit castell pot e deu esser a ells donada e acomanada, e no a altra persona alguna strangera. Per alguns bons respectes concerne[n]ts servey de vostra magestat e gran útil e beneffici de la dita vila e aldees e habitadors d'aquelles, haurem, senyor molt excelent, a molta e singular gràcia, vostra magestat los ne vulla complaure, perquè 's troben en tal punt constituïts e diminuïts, per infortunis de temps e mortalitats, que han necessària molta ajuda, comport e reparació. En açò, senyor, més avant serà provehit a la observança dels dits privilegis special que ells al leguen, e encara cessarà llur greuge axí manifest. Item, senyor, que, puix lo càrrech del dit castell sia llur de necessitat, se haurían a dispondre en donar-ne a vostra celsitut altre compte e rahó, que no faran si a ltre algú és acomanat. Supplicam vostra excel lència hi vulla pensar e voler-losne contentar. E haurem-ho a singular gràcia e mercé de vostra magestat, la qual nostre senyor Déus vulla longament conservar ab molta honor e exaltació de vostra real corona. Scrita en València a XXII dies de setembre de l'any MCCCCLXII.

Senyor, homils vassalls e servidors de vostra senyoria qui ‘s comanen en gràcia e mercé vostra, los jurts de València.

1462, octubre, 23.- Valencia.

Los jurats de Valencia envían cartas al rey y a Rodrigo de Rebolledo, separadamente, en las que, tras exponer la indefensión en que encuentra el castillo de Morella e insistir en que el nombramiento de este último como alcaide es contrario a la normativa legal, solicitan el cargo para Joan Ram.

—AMV, LM 25, ff. 124r-125r.

Sereníssimo senyor:

Dies ha que, per diverses vies, som avisats com lo castell de la vostra vila de Morella, lo qual és una insigne força e clau de vostre regne de València, sta en poder de hun Martí Armengol, laurador de les aldees de Morella, home degecte e de vil e pocha condició, dient-se sots-alcayt per frare Ferrer Ram, quondam alcayt del dit castell. E més, som avisats que lo dit castell sta sens armes, bombardes e altres provisions necessàries per la custòdia de aquell, com en aquell no y ha vitualles algunes ni algunes municions, e sens guardes e companya competents, car almenys serien necessaris XII o XV hòmens bons e fels per la defensió e guarda del castell, e de present no y ha sinó cinch o sis hòmens. E açò és cert a nosaltres, no solament per letres e per persones pròpries de la dita vila, a nosaltres trameses per aquella per haver de nosaltres consell, favor e ajuda sobre la guarda del castell, mas encara per actes públichs de protests fèts per lo dit sots-alcayt als lochtinent de batle, justícia e jurats de la dita vila, trellats dels quals trametem a la magestat vostra. E com sia cosa molt perillosa lo dit castell star en tal disposició, attés lo temps occorrent e lo vehinat que té de Alcanyiç e de la frontera de Cathalunya, que ab poch esforç de gent d'armes poria ésser pres lo dit castell, ço que seria poch servey de vostra magestat e total destrució de tot lo regne de València, e durant la malícia del 
Agustín Rubio Vela. Circunstancia familiar y entrada en la vida política del joven poeta valenciano Joan Escrivà (1461-1462)

temps occorrent faça gran dan als dits fets la provisió o concessió per vostra magestat feta de la alcaydia del dit castell a mossén Rodrigo de Rebolledo, lo qual, per privilegi atorgat a la dita vila, no pot ni deu haver lo dit offici, e açò dóna gran entrenyor als hòmens de la dita vila, als quals, segons lo dit privilegi, pertany lo dit offici, vehents no ésser-los servats lo dit privilegi e ésser deseretats de semblant offici, lo qual a qualsevol de aquells seria gran honor e utilitat, e per ço hagen a gran molèstia la dita provisió, e voldrien que lo dit offici recaygués en home habitador de la dita vila, axí com és En Johan Ram, donzell, lo qual té casa e habitador e moltes altres heretats en la dita vila. E açò, senyor, ultra que sia conforme al dit privilegi e a la voluntat de la dita vila, encara seria gran servici de vostra magestat per ço que lo dit En Johan Ram, ab sos parents e amichs, e ab la bona disposició de aquell, ha potència e manera de observar e guardar aquell castell, ço que molt deu atendre vostra excel lència en tot temps, e senyaladament en aquest, lo qual se menega en tants perills. Supplicam, per tal, vostra magestat, axí homilment com podem, sia mercé vostra, per tots los dits respectes e altres que s’i porían aplicar, vulla benignament donar e atorgar lo dit offici al dit Johan Ram, ab tots lo[s] salaris e preminències de aquell, hagudes per revocades les provisions fetes al dit mossén Rebolledo del dit offici. O almenys sia mercé vostra proveyr que sia acomanat de present lo dit castell al dit En Johan Ram, e tota la custòdia de aquell, fins que en altra manera sia delliberat per vostra celsitut lo que serà fahedor de la dita alcaydia, hoÿts o convocats los hòmens de la dita vila, com no sia espedient al vostre servici que sens convocar-los proveesca vostra magestat a alguna persona de la dita alcaydia, e que sia manat als batles general de regne de València e de la dita vila que, en lo entretant, respongen al dit En Johan Ram del salari pertanyent a l'alcayt del dit castell, e ncara fornexquen aquell de armes, vitualles e altres monicions necessàries al dit castell. E haurem-ho a molt singular gràcia e mercé de vostra excel lència, la qual nostre senyor Déus vulla longament conservar, ab exaltació de molta honor e prosperitat. De València, a XXIII dies d'octubre de l'any MCCCCLXII.

Senyor, de vostra magestat humils vassalls e servidors, qui 's comanen en gràcia e mercé vostra, los jurats de València.

Fuit facta altra similis, mutatis mutandis, sub eodem kalandario directa al noble mossén Rodrigo de Rebolledo.

A tota vostra honor e complacència bé apparellats, los jurats de València.

1464, abril, 14.- Valencia.

El clavari de la ciudad registra la entrega a Joanot Ram, heredero universal de misser Ferrer Ram, del dinero que le correspondía como propietario de un censo municipal que ha cancelado, procedente de la herencia del jurista.

-AMV, CCo O-33, ff. 83v-84v.

Item, paguí e doní a l'honorable En Johanot Ram, donzell, habitador de la dita ciutat, hereu universal de tots els béns e drets que quondam foren del magnifich micer Ferrer Ram, doctor en leys, prothonotari del senyor rey, segons consta de la dita herència ab lo derrer testament de aquell, fet en la ciutat de Nàpols a XXV de setembre de l'any MCCCCXXXXVIII, indictione XII ${ }^{a}$, en poder del discret En Gabriel de Risio, notari públich, e publicat en la ciutat de València a IIII de dehembre de l'any MCCCCLXI, en poder del discret 
Agustín Rubio Vela. Circunstancia familiar y entrada en la vida política del joven poeta valenciano Joan Escrivà (1461-1462)

En Jacme Gisquerol, notari, mil cinchcentes trenta dues lliures, dos sous, cinch diners reyals, és a saber: MD lliures per preu o quitament de aquells $\mathrm{II}^{\mathrm{m}}$ sous censals que havia sobre la universitat de la dita ciutat, paguadors cascun any a XXVI de dehembre, abril e agost, los quals ça enrere per l'onorable e discret En Johan Maromà, notari, tunch síndich de la universitat de la dita ciutat, foren venuts e originalment carregats sobre los béns de la dita universitat al dit honorable micer Ferrer Ram ab carta rebuda per lonorable En Jacme Beneyto, notari, scrivà de la Sala, a VI de abril de lany MCCCCXXXXV, segons en aquella és larch contengut, per quitament del qual censal per vostre síndich, ab assentiment, ferma e voluntat de vosaltres, en virtut de lhonorable consell celebrat en la Sala de la dita ciutat a VIIII de maig de lsany MCCCCXIIII e confermat per altre consell celebrat en la dita Sala a XIII de març de lany MCCCCXXXIII, per les rahons en los dits consells larch contengudes, ne són stats fets IIII $^{\mathrm{e}}$ carregaments de censal sobre la dita universitat, cascú de $\mathrm{D}$ sous censals, la hun a $\mathrm{N}$ Luís de Benviure, mercader, l'altra a $\mathrm{Na}$ Damiata, donzella, filla de Lorenç Balester, l'altre a $\mathrm{N}$ Jacme Martínez de Sentàngel, l'altre a N Gil Roïç, fill de N'Anthoni Roïç, a messió, emperò, e despeses de aquells, ab IIII ${ }^{e}$ cartes públiques rebudes per lo dit En Jacme Beneyto, notari, a X de març propassat, segons en aquelles appar; e XXXII lliures, II sous, V diners per pensió prorata del dit censal quitat, comptada de III mesos XXII dies, fins a XVIIII de dehembre propassat, en lo qual dia lo dit En Johanot Ram feu e fermà quitament del dit censal en poder del dit notari e scrivà on és clar veure. E ha-n’i albarà dels dits magnífichs jurats, fet en València a XIIII de abril de l'any MCCCCLXIIII: Im D XXXII lliures, II sous, V [diners]. 
Agustín Rubio Vela. Circunstancia familiar y entrada en la vida política del joven poeta valenciano Joan Escrivà (1461-1462)

\section{Bibliografía}

Baydal Sala, V. (2008) La señoría de Beniparrell: de los Romaní a los Escrivà de Romaní (1258-1426), Beniparrell, Ayuntamiento de Beniparrell.

Blasco de Lanuza, Vincenzio (1622) Historias ecclesiasticas y seculares de Aragon, en que se continnuan los Annales de Curita, desde el Año 1556 basta el de 1618. Tomo segundo, Zaragoza, Juan de Lanaja y Quartanet.

Canellas, Ángel, ed. (1980) Jerónimo Zurita, Anales de la Corona de Aragón, vol. 6, Zaragoza, C.S.I.C., Institución «Fernando el Católico».

Carriazo, Juan de M., ed. (1946) Crónica del Halconero de Juan II, Pedro Carrillo de Huete, Madrid, Espasa-Calpe.

Cingolani, Stefano M. (1998) Joan Roís de Corella: La importància de dir-se honest, Valencia, E. Climent ed..

Cruselles, Enrique (1989) El maestre racional de Valencia. Función politica y Desarrollo Administrativo del Oficio Público en el siglo XV, Valencia, Edicions Alfons el Magnànim.

Escolano, Gaspar (1611) Segunda parte de la Decada primera de la Historia de la Insigne y Coronada Ciudad y Reyno de Valencia, Valencia, Pedro Patricio Mey.

Ferrando, Antoni (2012) «Llengua i context cultural al Tirant lo Blanc. Sobre la identitat del darrer Joanot Martorell (1458-1465)», eHumanista, 22, pp. 623-668.

Furió, Antoni (2013) «Car la retòrica més se pertany a notaris que a cavallers. Escriptura, orgull de classe i autoria del Tirant», eHumanista/IVITRA, 4, pp. 150-164.

García Marsilla, J. V. (2002) Vivir a crédito en la Valencia medieval. De los orígenes del sistema censal al endeudamiento del municipio, Valencia, Universitat de València.

Garcia Sempere, Marinela (2002) Lo passi en cobles (1493). Estudi i edició, Alacant/Barcelona, Institut Interuniversitari de Filologia Valenciana.

Gascón, Sergi (1999) «Corelliana: l'amor dels orats», en Vicent Martines (ed.), Estudis sobre Joan Roís de Corella, Alcoi, Ed. Marfil, pp. 183-191.

Gual Camarena, M. (1950-51) «Fernando el Católico, primogénito de Aragón, rey de Sicilia y príncipe de Castilla (1452-74)», Saitabi, VIII, pp. 182-223.

—_. (1952) «Morella frente a Juan II de Aragón», Boletin de la , Sociedad Castellonense de Cultura, 28 (1952), pp. 493-519.

Narbona Vizcaíno, R. (1991) «Los Escrivà. Rasgos genealógicos de un linaje patricio. Proyección política y matrimonial», Anales de la Real Academia de Cultura Valenciana, 69, pp. 65-101.

Hauf i Valls, A. G. (2013) «Isabel de Villena. Vida y obra de una mujer excepcional, en la Valencia del siglo XV», en E. Callado Estela (coord.), Valencianos en la bistoria de la Iglesia, IV, Valencia, Facultad de Teología San Vicente Ferrer, pp. 9-108.

Hinojosa Montalvo, J. (2013) «Torneos y justas en la Valencia foral», Medievalismo, 23, pp. 209-240.

Iborra, Joan, ed. (2013) Martí de Viciana: Libro segundo de la Crónica de la inclita y coronada ciudad de Valencia y de su reino, Valencia, Universitat de València.

SCRIPTA, Revista internacional de literatura i cultura medieval i moderna, núm. 3 / juny 2014 / pp. 46-70

ISSN: 2340-4841 · doi:10.7203/SCRIPTA.3.3788 
Agustín Rubio Vela. Circunstancia familiar y entrada en la vida política del joven poeta valenciano Joan Escrivà (1461-1462)

Llorca, Fernando (s. d.) Sublevación del infante don Jaime de Aragón, seguida de la de su bijo del mismo nombre (1462-1477), Valencia, Talleres Prometeo.

López Rodríguez, C. (2005) Nobleza y poderpolitico en el reino de Valencia (1416-446), Valencia, Universitat de València.

Martos, Josep Lluís (2001) Les proses mitologiques de Joan Roís de Corella, Alacant/Barcelona, IIFV, Publicacions de l'Abadia de Montserrat.

Parisi, Ivan (2004) «La Correspondencia cifrada entre el rey Fernando el Católico y el embajador Joan Escrivà de Romaní i Ram», Pedralbes: revista d'bistòria moderna, 24, pp. 55-116.

- (2006-2007) «La famiglia Escrivà parente dei Borgia: Àngel Escrivà, figlio del maestro razionale del regno di Valencia, compagno di studi di Cesare e Giovanni Borgia), Revista Borja. Revista de l'Institut Internacional d'Estudis Borgians, 1, pp. 103-119.

Parisi, Ivan (2008-2009) «Els Escrivà, parents dels Borja: una continuació», Revista Borja. Revista de l'Institut Internacional d'Estudis Borgians, 2 [=Actes del II Simposi Internacional sobre els Borja], pp. 55-79.

Pérez Bosch, Estela (2011) Los poetas valencianos del Cancionero General (Valencia,1511 y 1514), Valencia, Institució Alfons el Magnànim.

Riquer, Martí de (1964) Història de la literatura catalana, III, Barcelona, Ariel.

Riquer, Martín de (1993) «Los escritores mossèn Joan Escrivà y el comendador Escrivà», Cultura Neolatina, 53 (1993), pp. 85-113.

Rodrigo Lizondo, M., ed. (2011) Melcior Miralles: Crònica i dietari del capellà d'Alfons el Magnànim, Valencia, Universitat de València.

Rubio Vela, A. (2001) «Del asedio de Buñol al de Balaguer. Los valencianos y la sublevación de Jaume d'Urgell (1413)», en G. Colón Domènech y R. Pardo Camacho (eds.), De re militari [=Boletín de la Sociedad Castellonense de Cultura LXXVII], Castelló de la Plana, pp. 155-217.

. (2003) «Urgelistas valencianos. Sobre la oposición a Fernando I de Trastámara», Anuario de Estudios Medievales, 33/1, pp. 191-261.

. (2013) «El context històric de Joan Roís de Corella. Tríptic documental sobre el seu entorn», Afers, 76, pp. 593-615.

Segura y Barreda, J. (1868) Morella y sus aldeas. Corografía, Estadística, Historia, Tradiciones, Costumbres, Industria, Varones Ilustres etc. de esta antigua población y de las que fueron sus aldeas, Morella, Imp. de F. Javier Soto, 3 vols.

Tomás Botella, B. (2013) «En los orígenes de la hacienda inquisitorial valenciana: la inspección de las cuentas del receptor Joan Ram Escrivà (1482-1487)», en J. M ${ }^{a}$ Cruselles Gómez, coord., En el primer siglo de la Inquisición española. Fuentes documentales, procedimientos de análisis, experiencias de investigación, Valencia, Universitat de València, pp. 251-272.

Torre y del Cerro, A. de la (1926) Precedentes de la Universidad de Valencia, Valencia, Imprenta hijo de F. Vives Mora.

Ventura, Jordi (1978) Inquisició espanyola i cultura renaixentista al País Valencià, Valencia, Eliseu Climent ed.

Vicens Vives, J. (2006) Historia crítica de la vida y reinado de Fernando II de Aragón, ed. M. A. Marín Gelabert, Zaragoza, Institución Fernando el Católico.

SCRIPTA, Revista internacional de literatura i cultura medieval i moderna, núm. 3 / juny 2014 / pp. 46-70

ISSN: 2340-4841 · doi:10.7203/SCRIPTA.3.3788 